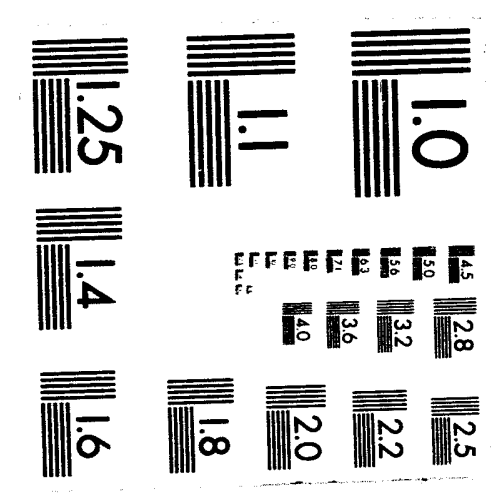



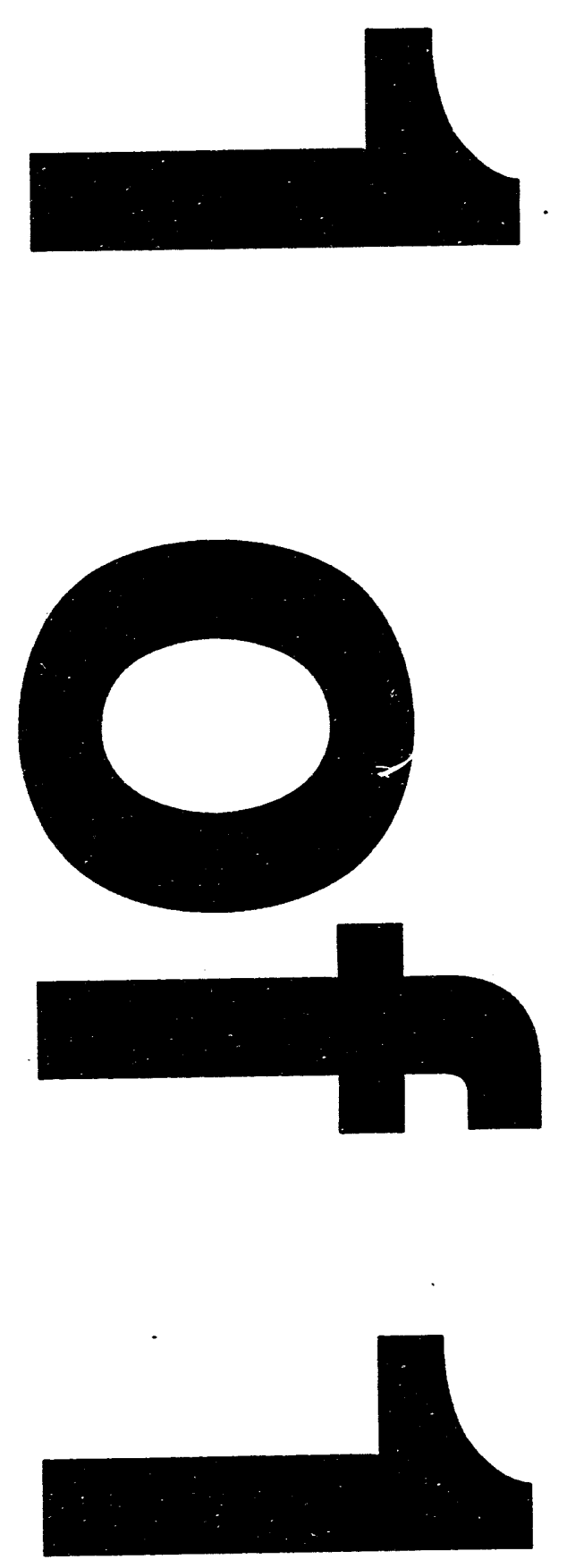
ORNL/ER-200

Energy Systems Environmental Restoration Program

ORNL Environmental Restoration Program

\title{
Meteorological Monitoring Sampling and Analysis Plan for Environmental Monitoring in Waste Area Grouping 6 at Oak Ridge National Laboratory, Oak Ridge, Tennessee
}

Date Issued-December 1993

\author{
Prepared by \\ CDM Federal Programs Corporation \\ Oak Ridge, Tennessee \\ under subcontract 96B-99052C
}

CDM Document Control No. 7913-301-FR-BBFY

Prepared for U.S. Department of Energy

Office of Environmental Restoration and Waste Management under budget and reporting code EW 20

\section{OAK RIDGE NATIONAL LABORATORY}

Oak Ridge, Tennessee 37831-6285 managed by

MARTIN MARIETTA ENERGY SYSTEMS, INC. for the

U.S. DEPARTMENT OF ENERGY under contract DE-AC05-84OR21400 
Meteorological Monitoring Sampling and Analysis Plan for the Environmental Monitoring Plan in Waste Area Grouping 6 at Oak Ridge National Laboratory, Oak Ridge, Tennessee

Approvals

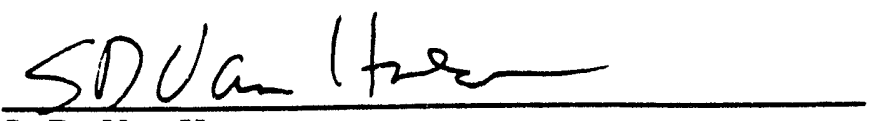

S. D. Van Hoesen

WAG 6 Project Manager

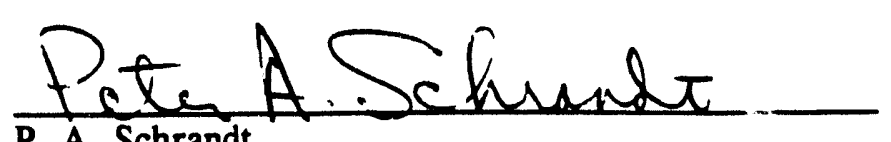

P. A. Schrandt Environmental Restoration Quality Assurance Specialist

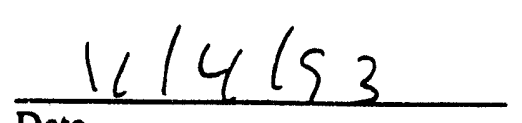

Date

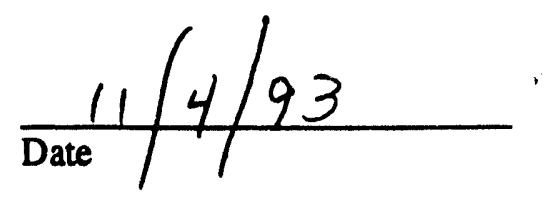




\section{CONTENTS}

FIGURES $\ldots \ldots \ldots \ldots \ldots \ldots \ldots \ldots \ldots \ldots \ldots \ldots \ldots$

TABLES $\ldots \ldots \ldots \ldots \ldots \ldots \ldots \ldots \ldots \ldots \ldots \ldots \ldots \ldots \ldots \ldots \ldots \ldots$

ABBREVIATIONS $\ldots \ldots \ldots \ldots \ldots \ldots \ldots \ldots \ldots \ldots \ldots \ldots \ldots \ldots \ldots \ldots$

EXECUTIVE SUMMARY $\ldots \ldots \ldots \ldots \ldots \ldots \ldots \ldots \ldots \ldots \ldots \ldots$

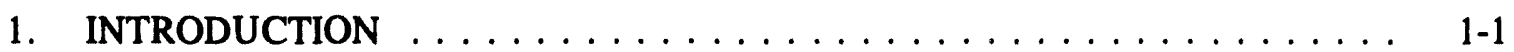

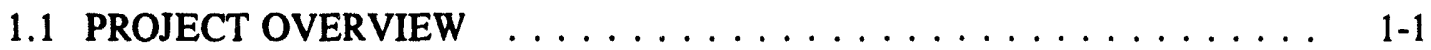

1.2 METEOROLOGICAL MONITORING SAP OUTLINE AND OBJECTIVE 1-1

1.3 SAMPLING LOCATIONS AND FREQUENCIES $\ldots \ldots \ldots \ldots \ldots$

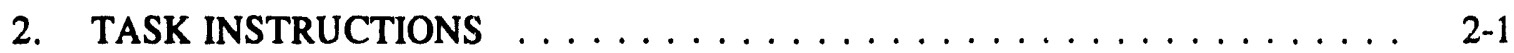

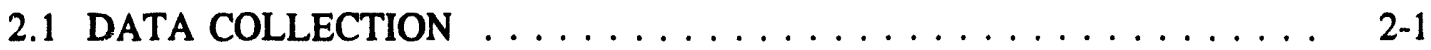

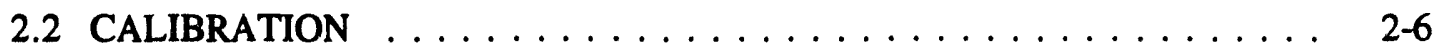

3. QUALITY ASSURANCE/QUALITY CONTROL REQUIREMENTS . . . . . 3-1

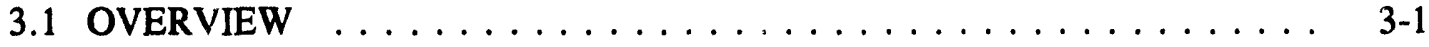

3.2 MONITORING PROGRAM ORGANIZATION $\ldots \ldots \ldots \ldots \ldots \ldots$

3.3 FIELD DOCUMENTATION . . . . . . . . . . . . . . 3-2

3.4 ACTIVITY-SPECIFIC QUALITY ASSURANCE/QUALITY

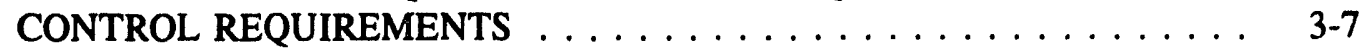

4. HEALTH AND SAFETY CONSIDERATIONS $\ldots \ldots \ldots \ldots \ldots \ldots \ldots$ 4-1

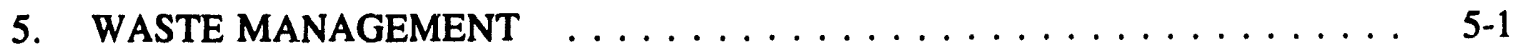

5.1 ORGANIZATIONAL RESPONSIBILITIES $\ldots \ldots \ldots \ldots \ldots \ldots \ldots$ 5-1

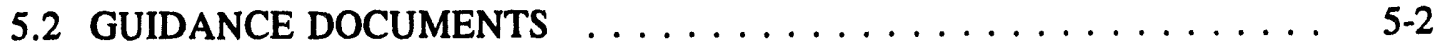

5.3 WASTE CHARACTERIZATION/SEGREGATION $\ldots \ldots \ldots \ldots \ldots \ldots$

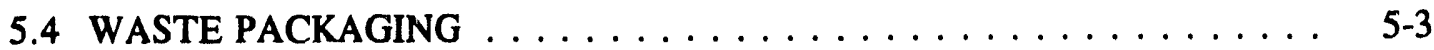

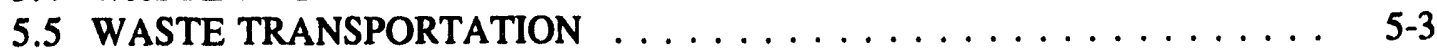

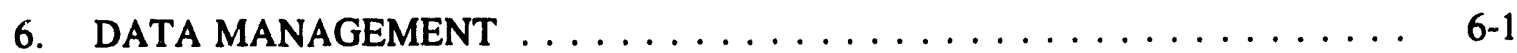

6.1 INTRODUCTION $\ldots \ldots \ldots \ldots \ldots \ldots \ldots \ldots \ldots \ldots$ 6-1

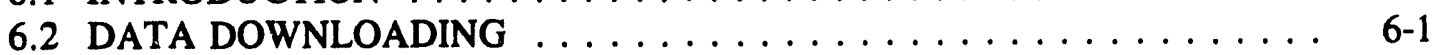

6.2.1 Electronic Data . . . . . . . . . . . . . . . . . 6 6-1

6.3 PROCEDURES FOR COMPLETING METEOROLOGICAL

MONITORING (MM) FORMS . . . . . . . . . . . . . . . . 6-2

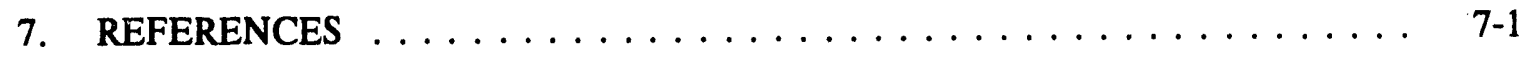

APPENDIX A: FIELD FORMS $\ldots \ldots \ldots \ldots \ldots \ldots \ldots \ldots \ldots \ldots \ldots$ A-1

APPENDIX B: SITE-SPECIFIC HAZARD EVALUATION ADDENDUM FOR WAG 6 METEOROLOGICAL MONITORING . . . . . . . . B-1 


\section{FIGURES}

1.1. Location of meteorological station at WAG $6 . \ldots \ldots \ldots \ldots$. . . . . . . . . .

2.1. Meteorological monitoring activity flowchart. . . . . . . . . . . . . . . 2-4

3.1. CDM Federal WAG 6 Environmental Monitoring Plan implementation

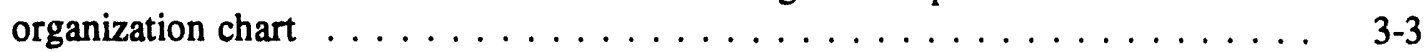




\section{TABLES}

1.1. WAG 6 Meteorological Monitoring SAP and project-level

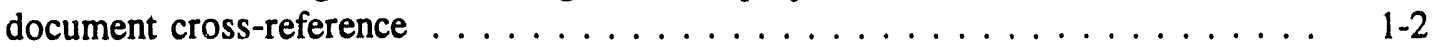

1.2. Meteorological parameters to be monitored $\ldots \ldots \ldots \ldots \ldots$

2.1. Frequencies of meteorological monitoring activities $\ldots \ldots \ldots \ldots$. . . . . .

2.2. Critical equipment for meteorological monitoring station $\ldots \ldots \ldots \ldots$. . . . .

3.1. General responsibilities of WAG 6 EMP principal contractor personnel . . . . . . 3-4

3.2. Types of field documentation and their required information $\ldots \ldots \ldots \ldots$

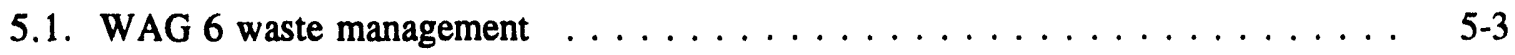




\section{ABBREVIATIONS}

$\begin{array}{ll}\text { ASME } & \text { American Society of Mechanical Engineers } \\ \text { CDM Federal } & \text { CDM Federal Programs Corporation } \\ \text { CFR } & \text { Code of Federal Regulations } \\ \text { DM } & \text { Data Manager } \\ \text { DOE } & \text { U.S. Department of Energy } \\ \text { DSP } & \text { data storage pack } \\ \text { EMP } & \text { Environmental Monitoring Plan } \\ \text { Energy Systems } & \text { Martin Marietta Energy Systems, Inc. } \\ \text { ESML } & \text { Energy Systems Met Lead } \\ \text { ESP } & \text { environmental surveillance procedure } \\ \text { EPA } & \text { U.S. Environmental Protection Agency } \\ \text { FOP } & \text { field operations procedure } \\ \text { FTM } & \text { Field Task Manager } \\ \text { GCO } & \text { Generator Certification Official } \\ \text { H\&S } & \text { health and safety } \\ \text { HD } & \text { high density } \\ \text { HP } & \text { Health Physics Section } \\ \text { I\&C } & \text { Instrumentation and Controls } \\ \text { ID } & \text { identification } \\ \text { IH } & \text { Industrial Hygiene Section } \\ \text { LGWOD } & \text { Liquid and Gaseous Waste Operations Department } \\ \text { MM } & \text { Meteorological Monitoring } \\ \text { OREIS } & \text { Oak Ridge Environmental Information System } \\ \text { ORNL } & \text { Oak Ridge National Laboratory } \\ \text { OSHA } & \text { Occupational Safety and Health Administration } \\ \text { PC } & \text { personal computer } \\ \text { PPE } & \text { personal protective equipment } \\ \text { QA } & \text { quality assurance } \\ \text { QC } & \text { quality control } \\ \text { RCRA } & \text { Resource Conservation and Recovery Act } \\ \text { SAP } & \text { sampling and analysis plan } \\ \text { SHSO } & \text { Site Health and Safety Officer } \\ \text { SLLW } & \text { solid low-level waste } \\ \text { STL } & \text { Sample Task Leader } \\ \text { SWSA } & \text { solid waste storage area } \\ \text { WAG } & \text { waste area grouping } \\ \text { WMO } & \text { Waste Management Operations } \\ \text { WMP } & \end{array}$




\section{EXECUTIVE SUMMARY}

This Sampling and Analysis Plan addresses meteorological monitoring activities that will be conducted in support of the Environmental Monitoring Plan for Waste Area Grouping (WAG) 6. WAG 6 is a shallow-burial land disposal facility for low-level radioactive waste at the Oak Ridge National Laboratory, a research facility owned by the U.S. Department of Energy and managed by Martin Marietta Energy Systems, Inc. Meteorological monitoring of various climatological parameters (e.g., temperature, wind speed, humidity) will be collected by instruments installed at WAG 6. Data will be recorded electronically at frequencies varying from 5-min intervals to 1-h intervals, dependent upon parameter. The data will be downloaded every 2 weeks, evaluated, compressed, and uploaded into a WAG 6 data base for subsequent use. The meteorological data will be used in water balance calculations in support of the WAG 6 hydrogeological model. 


\section{INTRODUCTION}

\subsection{PROJECT OVERVIEW}

This document is the Meteorological Monitoring Sampling and Analysis Plan (SAP) for Waste Area Grouping (WAG) 6 at Oak Ridge National Laboratory (ORNL). Note that the document is referred to as a SAP even though no sampling and analysis will be conducted as part of this activity. The term SAP is used for consistency. The procedures described herein are part of the Environmental Monitoring Plan (EMP) for WAG 6, which also includes monitoring tasks for groundwater quality, groundwater levels, seeps and springs, and surface water parameters. Separate SAPs are being issued concurrently to describe each of these monitoring programs.

This SAP has been written for the use of the field personnel who are responsible for implementing the EMP, with the intent that the field personnel will be able to take this document to the field and quickly find the appropriate steps required to complete a specific task. In many cases, Field Operations Procedures (FOPs) or equipment manuals will define the steps required for an activity. The FOPs for the EMP and the equipment manuals are referenced and briefly described in the relevant sections of the plans, and are contained within the FOP Manual. Both these documents (the SAP and the FOP Manual) will be available to personnel in the field.

Information regarding the WAG 6 physical description, geology and hydrogeology, and waste disposal and regulatory history can be found in the Resource Conservation and Recovery Act Facility Investigation Report for Waste Area Grouping 6 at Oak Ridge National Laboratory, Oak Ridge, Tennessee (Energy Systems 1991), and a description of the purpose and scope of the EMP can be found in the Environmental Monitoring Plan for Waste Area Grouping 6 at Oak Ridge National Laboratory, Oak Ridge, Tennessee (DOE 1993a).

\subsection{METEOROLOGICAL MONITORING SAP OUTLINE AND OBJECTIVE}

The purpuse of the meteorological monitoring SAP is to provide field workers with information on conducting activities that are unique and essential to accomplishing the task of measuring meteorological parameters. Some information that is important to field workers is contained in other project-level documents. To avoid duplication of this information [which includes project-level quality assurance/quality control (QA/QC) and health and safety (H\&S) protocols], other documents have been referenced as appropriate. Table 1.1 displays the organization of this SAP and the relevant reference documents. All documents will be made available to the field workers before the initiation of field activities, and these documents will be available at the field office. Copies of these reference documents will be available to the field workers to carry into the field for direct reference as the need arises.

The objective of the Meteorological Monitoring Program, as defined in the EMP, is to refine risk estimates through water balance calculations. Data on rainfall and evapotranspiration will be used to achieve understanding of the site water balance and to estimate groundwater flow. Field workers should keep this objective in mind when conducting the activities described in this SAP. An understanding of, and a constant adherence to, the objectives of the EMP will ensure the collection of data in quantities and at the quality level necessary to meet the objectives. 
Table 1.1. WAG 6 Meteorological Monitoring SAP and project-level document cross-reference

\begin{tabular}{|c|c|}
\hline Meteorological Monitoring SAP section & Project-level reference document(s) \\
\hline $\begin{array}{l}\text { Section } 1 \text { - Introduction contains limited } \\
\text { information on the EMP, summarizes project } \\
\text { objectives, and summarizes the meteorological } \\
\text { monitoring activities to be conducted. }\end{array}$ & DOE Environmental Monitoring Plan \\
\hline $\begin{array}{l}\text { Section } 2 \text { - Task Instructions identifies the } \\
\text { specific tasks to be conducted, contains activity- } \\
\text { specific instructions on the work to be } \\
\text { performed, and lists the procedures to be used at } \\
\text { various stages of the work. }\end{array}$ & $\begin{array}{l}\text { DOE Environmental Monitoring Plan; } \\
\text { WAG } 6 \text { Field Operations Procedures Manual }\end{array}$ \\
\hline $\begin{array}{l}\text { Section } 3 \text { - Quality Assurance/Quality Control } \\
\text { Requirements contains information on the } \\
\text { QA/QC requirements specific to meteorological } \\
\text { monitoring. This section includes information } \\
\text { on documentation. }\end{array}$ & $\begin{array}{l}\text { DOE Quality Assurance Project Plan for } \\
\text { Characterization and Monitoring Activities in } \\
\text { Waste Area Grouping } 6 \text { at Oak Ridge National } \\
\text { Laboratory }\end{array}$ \\
\hline $\begin{array}{l}\text { Section } 4 \text { - Health and Safety Considerations } \\
\text { briefly describes the health and safety aspects of } \\
\text { the activity. Activity-specific Instruction Sheets } \\
\text { (located in Appendix B) are referenced in this } \\
\text { section, and will address specific health and } \\
\text { safety issues that are not covered by the Site } \\
\text { Health and Safety Plan. }\end{array}$ & $\begin{array}{l}\text { Energy Systems Site Health and Safety Plan for } \\
\text { Waste Area Grouping } 6 \text { at Oak Ridge National } \\
\text { Laboratory }\end{array}$ \\
\hline $\begin{array}{l}\text { Section } 5 \text { - Waste Management briefly } \\
\text { describes the waste management associated with } \\
\text { the meteorological monitoring. The wastes } \\
\text { associated with this activity will be restricted to } \\
\text { personal protective equipment and other trash } \\
\text { items such as used paper towels. }\end{array}$ & Energy Systems Waste Management Plan \\
\hline $\begin{array}{l}\text { Section } 6 \text { - Data Management describes the } \\
\text { data collection and management activities that } \\
\text { will be conducted in the field, and the } \\
\text { procedures for collecting these data to ensure } \\
\text { that accurate data are transferred into the } \\
\text { database. }\end{array}$ & $\begin{array}{l}\text { Energy Systems Data Management } \\
\text { Plan/Functional Systems Design }\end{array}$ \\
\hline
\end{tabular}

The meteorological monitoring system will consist of a stand-alone tower and meteorological instruments connected to an electronic data logger for continuous data acquisition. The Tumulus Meteorology Station will be used for this effort. With the exception of the precipitation gauge, which will be mounted at ground level, the meteorological instrumentation will be mounted on the tower.

The following paragraphs describe the instrumentation that will be used to measure the indicated parameters. 
Wind speed and direction. The wind speed and direction will be measured with an R.M. Young (YOUNG, Model 0513) combined wind speed and wind direction monitor having a starting threshold of 1.12 miles per hour (mph) and an upper range of $112 \mathrm{mph}$.

Temperature and relative humidity. The atmosphere dry bulb temperature and relative humidity will be collected with a Vaisala temperature and relative humidity sensor (VAISALA, Model HMP 23 UT). This sensor uses a thin-film capacitive, relative-humidity-sensing element with a range of $-40^{\circ} \mathrm{C}$ to $80^{\circ} \mathrm{C}$. This unit will be placed in a naturally aspirating radiation shield (OMNIDATA, Model EA 130).

Precipitation. Precipitation will be measured using a WEATHERtronics Tipping Bucket Rain Gage (WEATHERtronics, Model 6011-A) having a mercury-wetted reed switch and a resolution of 0.01 in.

Solar radiation. Solar radiation data will be collected with a pyranometer (Li-Cor Model Li-2005) consisting of a silicon photovoltaic detector mounted in a cosine-corrected miniature head. This instrument measures the combined solar radiation emitted from the sky and sun.

Data from these activities will be collected electronically on various forms (see Appendix A), and in field logbooks.

\subsection{SAMPLING LOCATIONS AND FREQUENCIES}

The EMP specifies that the tumulus meteorology station, located approximately $25 \mathrm{ft}$ south of the Tumulus I pad, will be used for this monitoring effort (Fig. 1.1). The location of the meteorological tower is such that it will provide representative measurements of local air flow patterns in WAG 6. The location of the tower meets the U.S. Environmental Protection Agency (EPA) specification that no surface obstruction be located within a distance of 10 times the height of the instrument. This minimizes the probability of any air flow obstructions or artificially induced turbulence. The meteorological parameters to be monitored and the frequency of sampling are displayed in Table 1.2.

The meteorological station will be inspected semiweekly (twice weekly) to ensure that all instruments are functioning. The collected data will be downloaded from the various instruments biweekly (every two weeks), reduced and validated, and uploaded into the WAG 6 data base. 

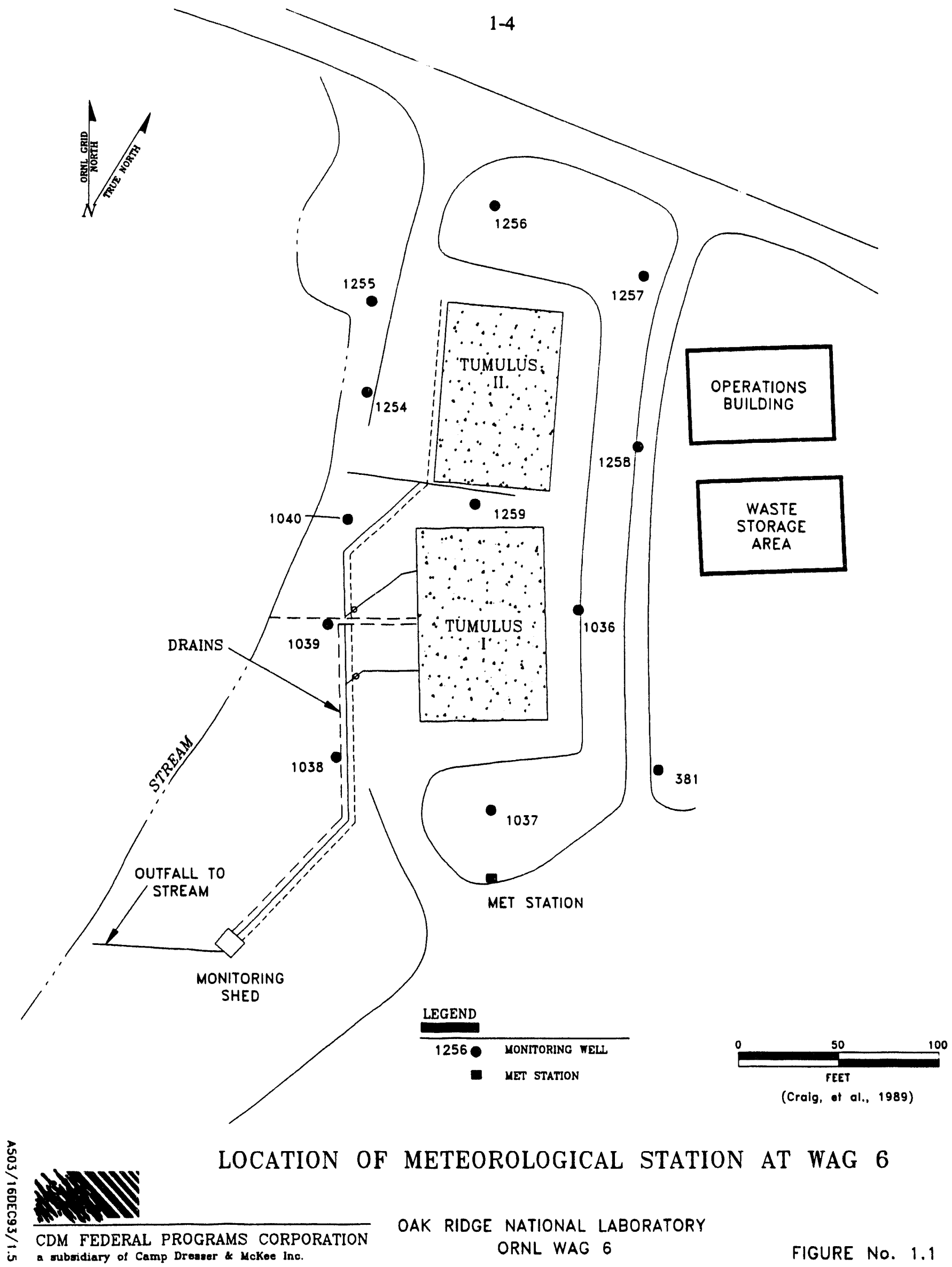

OAK RIDGE NATIONAL LABORATORY

ORNL WAG 6

FIGURE No. 1.1 
Table 1.2. Meteorological parameters to be monitored

\begin{tabular}{ccc}
\hline Meteorological parameter & Sample interval & $\begin{array}{c}\text { Data logger } \\
\text { averaging period }\end{array}$ \\
\hline Wind speed & $1 \mathrm{~min}$ & $1 \mathrm{~b}$ \\
Wind direction & $1 \mathrm{~min}$ & $1 \mathrm{~h}$ \\
Dry bulb temperature & $1 \mathrm{~min}$ & $1 \mathrm{~h}$ \\
Relative humidity & $1 \mathrm{~min}$ & $1 \mathrm{~h}$ \\
Solar radiation & $1 \mathrm{~min}$ & $1 \mathrm{~h}$ \\
Precipitation & Pulse counter & $5 \mathrm{~min}$ \\
\hline
\end{tabular}

a All the data to be gathured in this effort are field data; no laboratory analysis will be involved. Accordingly, the meteorological measurement data are to be considered QC Level I. 


\section{TASK INSTRUCTIONS}

This section identifies the specific meteorological monitoring tasks to be performed to meet the objectives of the EMP. In all cases, fieldwork will be accomplished according to this SAP. Any deviations from this SAP will be documented on a WAG 6-Monitoring Variance Request Form (MV-01) and approved before implementation. If for any reason a task is not completed, the reason also will be documented on a WAG 6-Monitoring Variance Request Form (MV-01) and in the field logbook. Any problem or corrective action taken will be documented on the WAG 6-Site Inspection/Data Collection Form (MM-02) and in the field logbook.

The collection of meteorological data is entirely automated. Field technicians are required only to collect data biweekly from the 32K EPROM Data Storage Pack (DSP) and to perform periodic calibration on the instruments (see Table 2.1). Inspections of the meteorological station will be conducted semiweekly to ensure that the instruments are functioning.

Because all instruments were originally part of the Tumulus Disposal Demonstration Project (Miller, Black, and Craig 1989), no installation is necessary. The location of the meteorological monitoring station has not changed, and all instruments are presently installed on the tower on site. Table 2.2 is a list of equipment that is necessary for the monitoring to take place.

A flowchart of the tasks to be conducted as part of this activity is displayed in Fig. 2.1. This flowchart graphically depicts the sequence in which the tasks will be conducted, the decision points associated with conducting the tasks, and when information will be recorded for data collection and management.

\subsection{DATA COLLECTION}

All meteorological parameters are to be sampled continuousiy with an OMNIDATA Easy Logger. The number of instruments and the reporting interval are such that a 32K EPROM DSP may be left in the field for as long as one month. However, all data from this instrument will be collected on alternate weeks.

To retrieve and install DSPs, the following equipment is necessary:

- $\quad$ surgical gloves and/or additional personal protective equipment (PPE) as specified by the

Site Health and Safety Officer (SHSO) and/or Site Health Physicist,

- $\quad$ Easy Logger field unit (at site),

- key to Easy Logger protective case,

- $\quad$ Easy Logger terminal (hand-held),

- Easy Logger manual,

- 3/8-in. hexagonal wrench, 
Table 2.1. Frequencies of meteorological monitoring activities

\begin{tabular}{lcccl}
\hline \multicolumn{1}{c}{ Instrument } & Parameter & $\begin{array}{c}\text { Data collection } \\
\text { frequency }\end{array}$ & $\begin{array}{c}\text { Inspection } \\
\text { frequency }\end{array}$ & \multicolumn{1}{c}{ Calibration frequency } \\
\hline Wind speed/direction sensor & $\begin{array}{c}\text { Wind } \\
\text { speed/direction } \\
\text { Temperature and } \\
\text { humidity }\end{array}$ & Biweekly & Semiweekly & Biannually \\
Humidity meter & Solar radiation & Biweekly & Semiweekly & $\begin{array}{l}\text { Must be returned to factory for recalibration every } \\
\text { Terrestrial radiation sensors }\end{array}$ \\
Tipping bucket rain gauge & Precipitation & Biweekly & Semiweekly & Annually \\
Data logger & - & - & Semiweekly & Lithium backup battery checked semiannually \\
\hline
\end{tabular}

a Additional inspections should be performed after electrical storms. 
Table 2.2. Critical equipment for meteorological monitoring station

\begin{tabular}{|c|c|c|c|}
\hline Equipment & Manufacturer & Model \# & $\begin{array}{c}\text { Total } \\
\text { quantity }\end{array}$ \\
\hline Hand terminal & Omnidata & EL-820 & 1 \\
\hline DSP 64K & Omnidata & EM-064 & 3 \\
\hline DSP eraser & Omnidata & PL-265T & 1 \\
\hline Universal configuration cable & Omnidata & UC-6 & 1 \\
\hline Desiccant & Omnidata & DC-245 & As needed \\
\hline DSP reader or spare Easy Logger (Office) & Omnidata & EL-800 & 1 \\
\hline Signal line Zapnots & Omnidata & ES-240 & $4^{a}$ \\
\hline Power line Zapnots & Omnidata & EA-242 & $5^{a}$ \\
\hline Zapnot bustrack & Omnidata & FEA-11 & 1 \\
\hline System grounding cable & Omnidata & Copper wire & 1 \\
\hline Easy Logger field unit & Omnidata & EL-824 & 1 \\
\hline Easy Logger multiplexer & Omnidata & EA-110 & 1 \\
\hline Radiation shield & Omnidata & EA-130 & 1 \\
\hline Rotronic $\mathrm{RH} /$ temperature probe & Rotronic & $\begin{array}{c}\text { MP100C-00/2 } \\
\text { (R28012) }\end{array}$ & 1 \\
\hline Easy Logger steel enclosure & Omnidata & EA-120 & 1 \\
\hline Tipping bucket rain gauge & WEATHERtronics & 6011-A & 1 \\
\hline Solar radiation sensor & $\mathrm{Li}-\mathrm{Cor}$ & $\mathrm{Li}-200 \mathrm{SZ}$ & 1 \\
\hline Wind speed/direction sensor & R.M. Young & 05103 & 1 \\
\hline Meteorological instrument tripod & Omnidata & EA-136 & 1 \\
\hline $12 \mathrm{~V}$ rechargeable battery & Johnson Controls & JC 1260 & 8 \\
\hline
\end{tabular}

- Four signal line Zapnots and five power line Zapnots must be available to use as spares. 


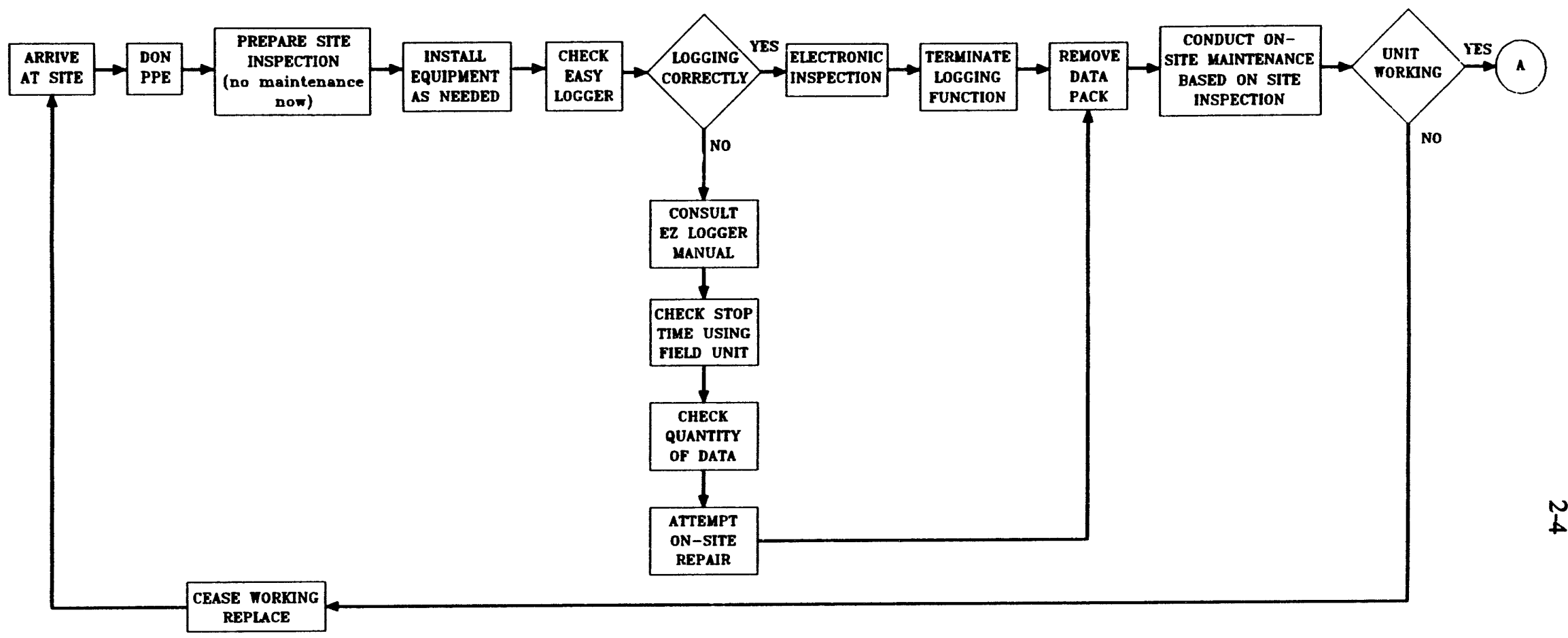

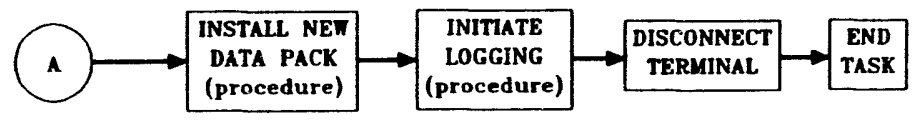


- empty EPROM DSP,

- field watch set to Instrumentation and Controls (I\&C) Division universal time,

- desiccant,

- bar code labels and bar code scanning equipment,

- field logbook,

- WAG 6-Meteorological Site Inspection/Data Collection Form (MM-02), and

- waterproof black ink pen.

Data collection will take place according to the WAG 6-Meteorological Site Inspection/Data Collection Form (MM-02). The following guidelines should be utilized when retrieving DSPs.

1. When first arriving on site, survey the condition of the station and write notes concerning its condition in the site logbook and on the comments section of the WAG 6-Meteorological Site Inspection/Data Collection Form (MM-02). Items to record include debris lodged in a device, evidence of tampering, or any change in the station since the previous inspection.

DO NOT ATTEMPT ANY MAINTENANCE OR REPAIR AT THIS TIME.

2. Open the Easy Logger field unit protective case and check the condition of the desiccant (which should be blue) and any ant traps or other environmental control devices. Note any changes necessary on the WAG 6-Meteorological Site Inspection/Data Collection Form (MM-02).

3. Attach the terminal to the field unit. Match the half-moon notch on the cable connector to the cut-out half-moon notch on the field unit. Then push the cable down firmly and turn the outer ring lock on the cable to tighten the connection.

4. Turn the unit on by pressing the on-off key. If the terminal is left on for several minutes during which no keys are pressed, it will turn itself off, but it will save previous entries.

5. Confirm that the data logger is in logging mode. The prompt "select an option" should appear with the word "logging" in parentheses beneath it. If it does, continue to step 6. If it does not, record stop time and quantity of data, and consult the Easy Logger manual to attempt repair.

6. Conduct electronic inspection according to the WAG 6-Meteorological Site Inspection/Data Collection Form (MM-02).

7. Terminate logging: type 00, NO (LOG RUN/STOP).

8. Physically remove the old, full DSP.

9. Bar code scan the old DSP. If maintenance indicated by site inspection will disrupt logging (e.g., jostling instruments, unplugging wires), perform maintenance now. If maintenance 
will not disrupt logging (e.g., cleaning rain gauge, replacing desiccant), complete steps 10 through 12 immediately and then perform maintenance. Note any variances on a WAG 6-Monitoring Variance Request Form (MV-01), in the field logbook, and on a WAG 6-Meteorological Site Inspection/Data Collection Form (MM-02); note any repairs on the WAG 6-Record of Repair Form (RF-01).

10. Confirm equipment is in working order. If it is, continue to Step 11. If it is not, repair or replace malfunctioning equipment and start process from Step 1.

11. Bar code scan the new, empty DSP.

12. Physically install the new DSP.

13. Resume logging: type 00, YES, YES.

14. Disconnect terminal from field unit; close protective box.

15. If any unit is to be retired at this point, the WAG 6-Record of Repair Form (RF-01) must be filed.

NOTE: If the Easy Logger is not logging correctly, consult the Easy Logger manual. Possible causes for incorrect logging include whether it was set for logging last time, the condition of the solar collector and lithium backup battery, and wiring connections. If it cannot be fixed in the field, collect the DSP and consult I\&C.

An extra site service inspection the day after a problem has been discovered will be conducted and recorded only in the field logbook to ensure that the problem has been corrected. It is possible that the problem noticed was a symptom of some other problem that was not fixed.

The battery check option applies to the power battery, not to the lithium backup battery. At the meteorological station, the battery is powered by the solar collector and may be greater than $12 \mathrm{~V}$. If it is less than $10.5 \mathrm{~V}$, the rechargeable battery should be replaced.

\subsection{CALIBRATION}

All instruments, including the Easy Logger, will be calibrated by the Energy Systems I\&C Division prior to the commencement of EMP data-gathering activities. I\&C will also be available to perform calibrations according to the schedule in Table 2.1. I\&C must be contacted by the Sample Task Leader to perform these activities. These calibration events must be recorded on the WAG 6-Meteorological Instrument Calibration/Field Check Form (MM-03) and in the equipment maintenance and calibration logbook.

The humidity gauge will be checked against a hand-held humidity gauge on a weekly basis. Other field calibration checks may be performed at any time. One straightforward method is to compare a portable instrument's readings to the last recorded values on the WAG 6-Meteorological Site Inspection/Data Collection Form (MM-02). The equipment manuals provide procedures for field calibrations of the rain gauge and wind speed/wind direction meter. All calibration checks will be documented on the WAG 6-Meteorological Instrument Calibration/Field Check Form (MM-03) and in the field logbook. 
Maintenance of the meteorological instruments is anticipated to be minimal. The WAG 6-Meteorological Site Inspection/Data Collection Form (MM-02) provides a checklist for an inspection that will be performed semiweekly and will include basic maintenance items. 


\section{QUALITY ASSURANCE/QUALITY CONTROL REQUIREMENTS}

\subsection{OVERVIEW}

This section identifies QA/QC aspects of the Quality Assurance Plan for Charucterization and Monitoring Activities at Waste Area Grouping 6, Oak Ridge National Laboratory, Oak Ridge, Tennessee (CDM Federal 1993) that are required to implement the EMP and this SAP. Subjects addressed in this section include, but are not limited to, monitoring program organization and personnel responsibilities, documentation procedures and protocols, monitoring QC requirements, and equipment calibration and maintenance. The $\mathrm{QA} / \mathrm{QC}$ considerations presented in this section have been developed to ensure that the data generated during all phases of the EMP will be of known quality and legally defensible.

Work on this assignment will be performed in accordance with the following:

- Environmental Restoration Quality Program Plan, ES/ER/TM-4/R3 (Energy Systems 1993);

- Interim Guidelines and Specifications for Preparing Quality Assurance Project Plans, QAMS-005/80 (EPA 1983);

- Quality Assurance Program Requirements for Nuclear Facilities, ASME NQA-1 (ASME 1989);

- Quality Assurance Project Plan for the Environmental Monitoring Program in Waste Area Grouping 6 at Oak Ridge National Laboratory, Oak Ridge, Tennessee, DOE/OR/011193\&D1 (DOE 1993b); and

- WAG 6 Field Operations Procedures Manual (CDM Federal 1993b).

This SAP has been reviewed for QA/QC requirements by the Contract QA Manager, who will maintain QA oversight for the duration of the project. In addition, all deliverables will be subject to technical review by CDM Federal Programs Corporation (CDM Federal) technical specialists. All deliverables presenting measurement data will be reviewed by the CDM Federal QA staff. A description of the project Data Quality Objectives can be found in the EMP and in the Quality Assurance Project Plan.

\subsection{MONITORING PROGRAM ORGANIZATION}

The EMP personnel comprise a sub-task team of the Monitoring and Laboratory Analysis Group, identified in the WAG 6 EMP (DOE 1993a). The principal contractor personnel assigned to conduct the WAG 6 EMP field activities are

- Charles Callis (Project Manager),

- David Johnson (QA Specialist),

- Donnie McCurry [Field Task Manager (FTM)],

- Patrick Gerbic [Meteorological Sample Task Leader (STL)],

- Michael Charko (Field Technician), and

- Richard Stout (Field QC Coordinator). 
Figure 3.1 shows the project organization, reporting relationships, and lines of authority for this project. General responsibilities are discussed in the following subsections. Other personnel will be assigned as necessary. The responsibilities of key team niembers are described in Table 3.1.

\subsection{FIELD DOCUMENTATION}

Field documentation shall consist of

- one master site logbook (to be maintained at field headquarters),

- an equipment maintenance and calibration logbook,

- a field logbook (to be maintained by the STL),

- a telephone logbook,

- project- and activity-specific field forms (see Appendix A), and

- bar code labels.

All documentation must be completed in waterproof black ink, and corrections must be marked through with a single line, dated, and initialed. Handwritten documents must be legible. Table 3.2 displays where, and what kind of, information must be recorded.

\section{Field Documentation Forms}

EMP field activities will be documented primarily on field documentation forms. The following forms, which are located in Appendix A, are to be used for the specific activities addressed in this SAP:

- WAG 6-Meteorological Monitoring Initialization Form (MM-01),

- WAG 6-Meteorological Site Inspection/Data Collection Form (MM-02),

- WAG 6-Meteorological Instrument Calibration/Field Check Form (MM-03),

- WAG 6-Monitoring Variance Request Form (MV-01), and

- WAG 6 - Record of Repair Form (RF-01).

Any information pertinent to the current field activity or field condition that is not requested on the field documentation form should also be entered in the "Comments" section of the form and in the field logbook. The forms used at each site will be numbered sequentially, using bar codes. The form bar code label will be attached at the bottom right of the form, and also entered into the field logbook. All field documentation forms will be transferred to a hardcover, threering, site notebook for temporary storage upon completion. In addition, any charts, oversize pages, and other printed material (e.g., sample times) pertinent to current field activities will be securely attached to the corresponding field documentation form and contained in the notebook. The form number of the corresponding field documentation form must be written somewhere on the attached material and contained in the notebook. On a weekly basis, the completed forms will be taken from the notebook and given to the Data Manager for entry into the data base. 


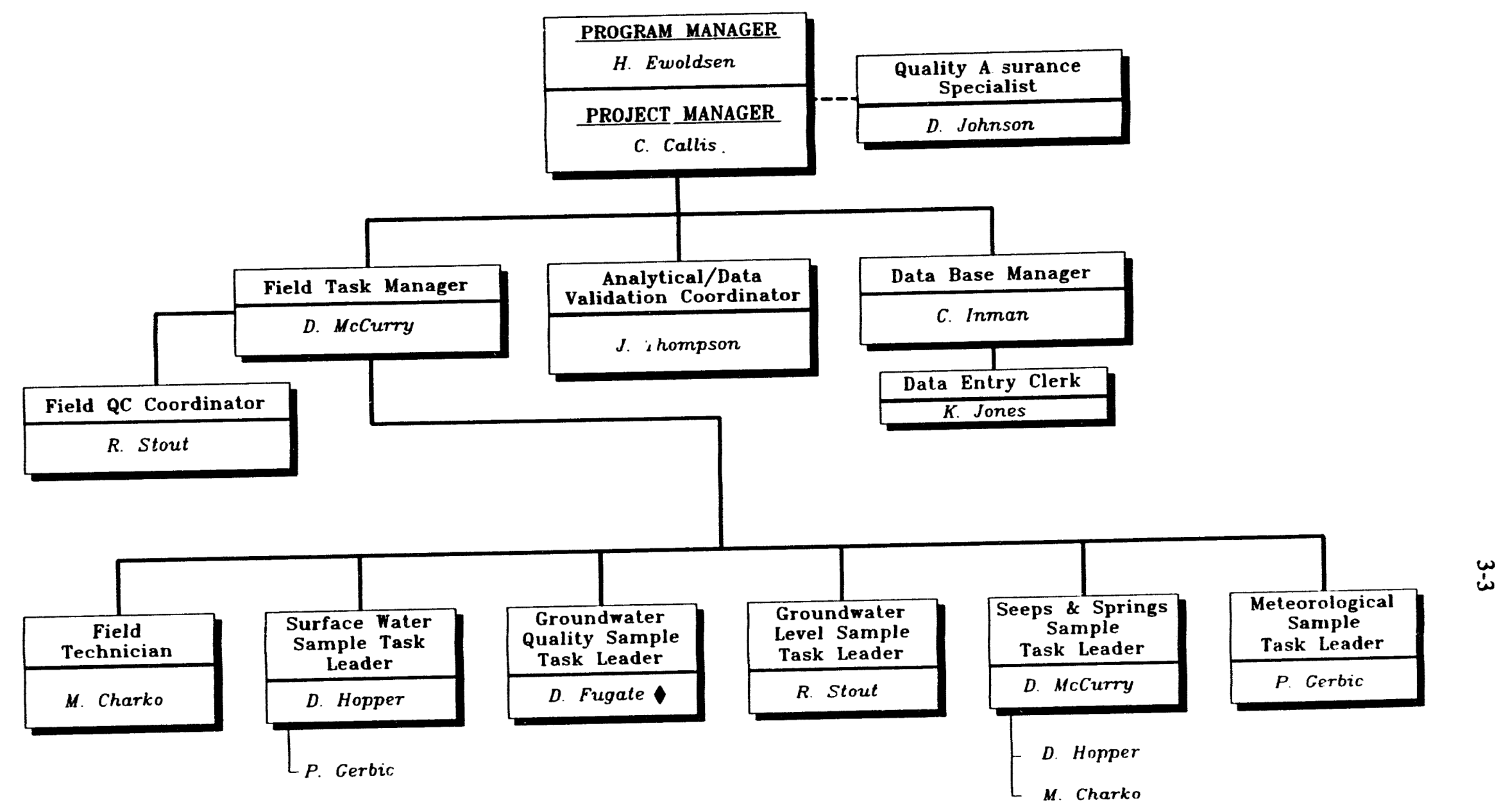

Note that the sampling will be conducted by OECD ESP

Note that $D$. Fugate will be responsible

personnel andation and sample management.

CDM FEDERAL WAG 6 ENVIRONMENTAL MONITORING

PLAN IMPLEMENTATION ORGANIZATION CHART

OAK RIDGE NATIONAL LABORATORY

OAK RIDGE, TENNESSEE

FIGURE No. 3.1 
Table 3.1. General responsibilities of WAG 6 EMP principal contractor personnel

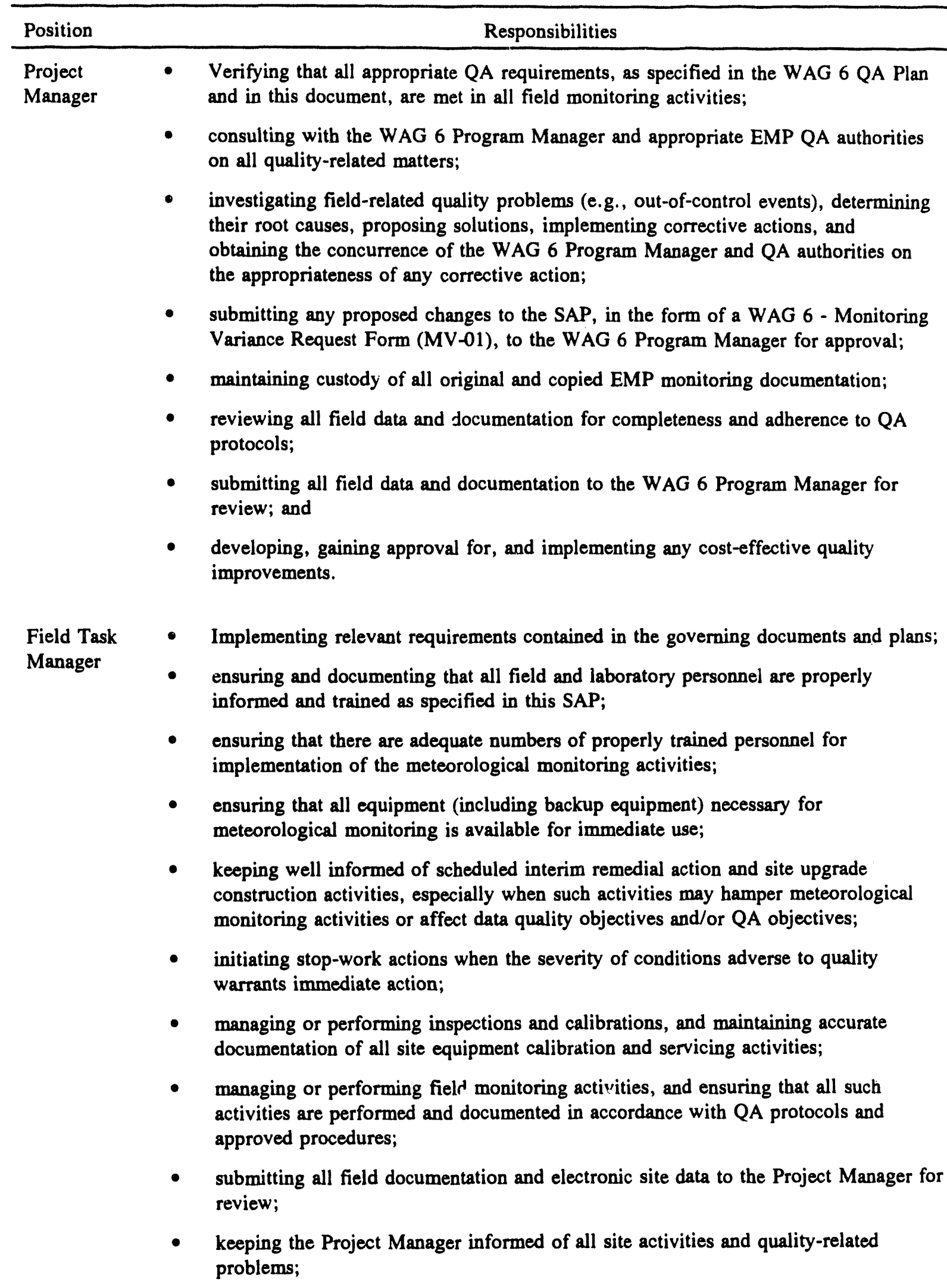


Table 3.1 (continued)

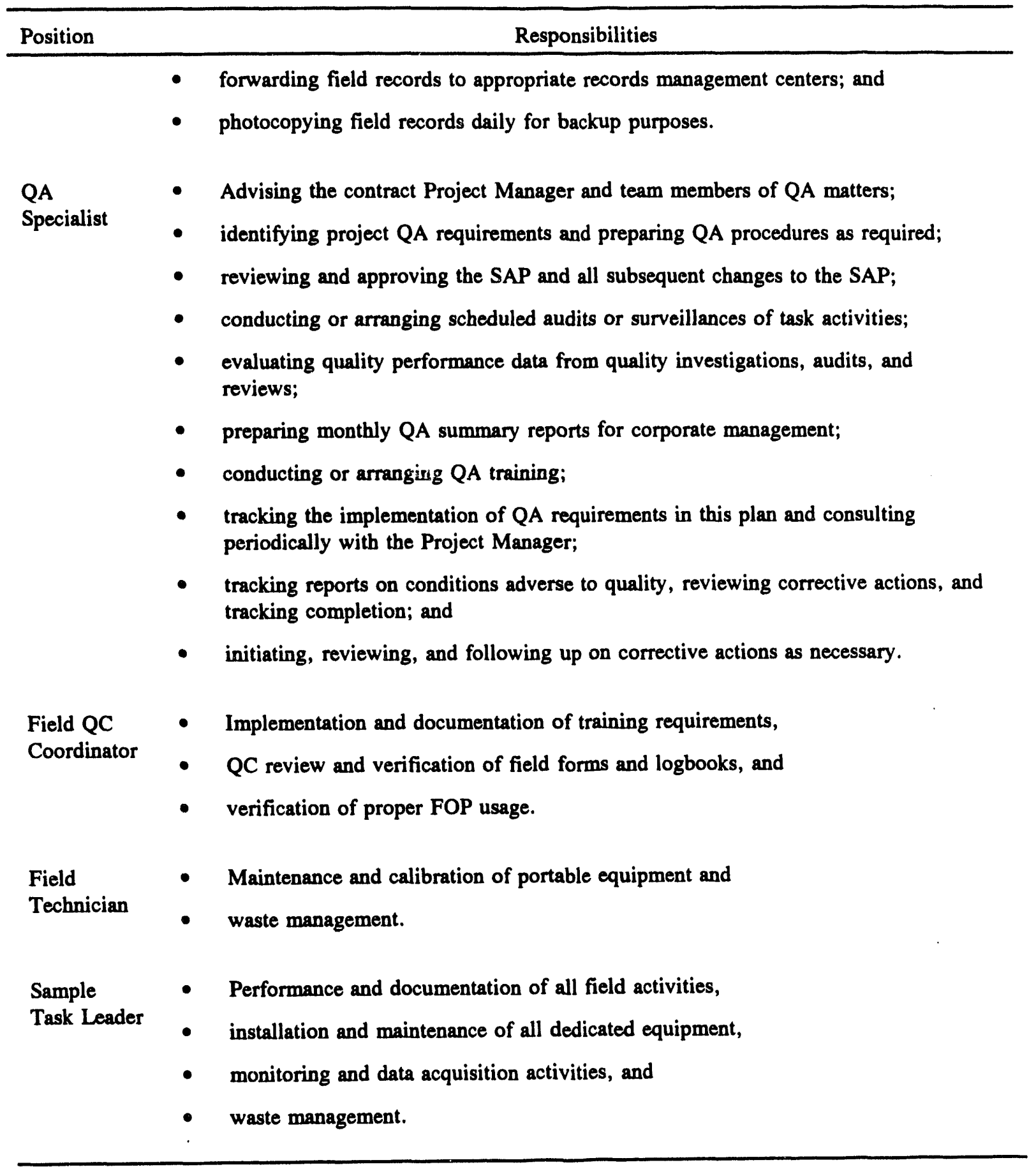


Table 3.2. Types of field documentation and the information required for each

\begin{tabular}{|c|c|}
\hline Field documentation & Information \\
\hline Site Logbook & $\begin{array}{l}\text { - A list of all field logbooks; } \\
\text { - daily temperature, weather conditions, and names and titles of } \\
\text { personnel present; } \\
\text { - name, title, organization, and purpose of site visitors; } \\
\text { - outline of daily activities; } \\
\text { - problems, their final resolution, and anticipated impact on the field } \\
\text { investigation; and } \\
\text { - field changes or variances. }\end{array}$ \\
\hline $\begin{array}{l}\text { Equipment } \\
\text { Maintenance and } \\
\text { Calibration Logbook }\end{array}$ & $\begin{array}{l}\text { - Equipment name, serial number, and identification (ID) number, } \\
\text { - date of each calibration event, } \\
\text { - identity of person performing calibration, and } \\
\text { - calibration settings and values. }\end{array}$ \\
\hline Field Logbooks & $\begin{array}{l}\text { - Date and time task started; weather conditions; and names, titles, and } \\
\text { organizations of personnel performing the task; } \\
\text { - a description of site activities in specific detail; } \\
\text { - a description, in detail, of any field test(s) (and results); } \\
\text { - a list of the time, equipment type and serial or identification number, } \\
\text { and procedure followed for decontamination activities; } \\
\text { - a list of equipment failures or breakdowns; and } \\
\text { - a description of calibration activities in the field. }\end{array}$ \\
\hline Telephone Logbook & $\begin{array}{l}\text { - Date of call, } \\
\text { - } \quad \text { time of call, } \\
\text { - } \quad \text { whether incoming or outgoing, } \\
\text { - participating parties, and } \\
\text { - } \quad \text { subject and pertinent information. }\end{array}$ \\
\hline
\end{tabular}




\subsection{ACTIVTTY-SPECIFIC QUALITY ASSURANCE/QUALITY CONTROL REQUIREMENTS}

All four meteorological monitoring instruments will be calibrated in accordance with the manufacturer's operating instructions before use. Thereafter, the instruments will be inspected and calibrated according to the following schedule:

\begin{tabular}{lll}
\hline \multicolumn{1}{c}{ Instrument } & \multicolumn{1}{c}{ Inspections } & \multicolumn{1}{c}{ Calibrations } \\
\hline RM Young Wind Speed/Direction Monitor & Every other Friday & $\begin{array}{l}\text { First and sixth month after } \\
\text { initiation of field activities }\end{array}$ \\
Rotronic temperature and RH sensor & Monday and Friday & $\begin{array}{l}\text { First and sixth month after } \\
\text { initiation of field activities }\end{array}$ \\
Li-Cor Pyranometer & Every other Friday & $\begin{array}{l}\text { Biannually } \\
\text { Annually }\end{array}$ \\
\hline
\end{tabular}

The inspections and calibrations (including calibration results) will be recorded in logbooks for each of the instruments. Additionally, the calibrations will be documented on the appropriate field documentation form. 


\section{HEALTH AND SAFETY CONSIDERATIONS}

The provisions of the project H\&S Plan are mandatory for all personnel assigned to the program. In no case may work be performed in a manner that is inconsistent with the intent and cautions expressed in the project H\&S Plan. All field personnel will be properly trained in H\&S regulations associated with handling hazardous materials and the safe operation of sampling equipment. As specified in 29 CFR 1910.120, all field personnel will have attended Occupational Health and Safety Administration (OSHA) 40-h hazardous waste worker training.

In general, personnel will work in groups or pairs. However, personnel will perform some work activities independently of other members of the WAG 6 field team. At these times, personnel will abide by a "buddy system." Each member of the WAG 6 field team will be responsible for keeping track of personnel working independently. Before leaving the monitoring area, all personnel and conveyed equipment will be checked with a beta-gamma meter for evidence of radiological contamination. Personnel will take precautions to help prevent contact with hazards identified in the project H\&S Plan.

Activity-specific H\&S considerations are addressed in task instructions located in Appendix B of this SAP. The SHSO and/or Site Health Physicist can modify the PPE required for site activities, tasks, and work zones. The SHSO and/or Site Health Physicist will train all site personnel in PPE donning and doffing procedures before initiating the EMP. 


\section{WASTE MANAGEMENT}

The WAG 6 EMP Waste Management Plan (WMP) states that CDM Federal, as waste generator, will perform waste segregation, packaging, labeling, and transportation activities as required during the project. CDM Federal is not responsible for final disposition of waste.

Anticipated wastes from meteorological monitoring activities include minimal volumes of various trash items such as used paper towels. No soil or purge water waste will be generated.

\subsection{ORGANIZATIONAL RESPONSIBILITIES}

The following personnel will be responsible for various aspects of WAG 6 waste management.

\section{Laboratory Certification Official}

The Laboratory Certification Official has the following responsibilities:

- implementing and managing the ORNL Solid Low-Level Waste (SLLW) Certification program,

- reviewing and approving project WMPs and WMP checklists, and

- $\quad$ providing direction if an unforeseen waste situation is encountered.

\section{Generator Certification Official}

The Generator Certification Official (GCO) has the following responsibilities:

- serving as interface between the project, the ORNL Labciatory Certification Official, and the ORNL WMO in addressing generator problems and waste certification requirements;

- initiating preparation of the Waste Pickup Request Form;

- certifying that the waste was packaged in accordance with the ORNL waste acceptance criteria, the ORNL SLLW certification program, and SLLW QA Plan requirements;

- making arrangements with WMO for pickup and transfer of waste packages to the designated storage or treatment facility; and

- assuming other duties as specified in the WMP.

\section{Field Task Manager}

The Field Task Manager has the following responsibilities:

- ensuring that site personnel follow the WMP,

- coordinating with Health Physics (HP) and Industrial Hygiene (IH), and 
- $\quad$ assuming responsibility for transportation of waste as required.

Sample Task Leader

As the generator, the Sample Task Leader has the following responsibilities:

- properly containerizing, packaging, and segregating all waste generated as part of the project;

- interfacing with the FTM to ensure that any issues pertaining to SLLW characterization are promptly brought to the attention of the responsible individuals and that any new certification requirements are promptly instituted;

- assisting the GCO with the preparation of the Waste Pickup Request Form and the Container Packing List; and

- assuming other duties as specified in the project WMP.

Health Physics and Industrial Hygiene Personnel

HP and IH personnel are responsible for conducting surveys as necessary to determine whether waste contains Resource Conservation and Recovery Act- (RCRA-) regulated or radiologically contaminated materials.

\subsection{GUIDANCE DOCUMENTS}

The following documents will provide guidance for waste management activities conducted during the implementation of the WAG 6 EMP.

- WAG 6 Project WMP,

- "Waste Management" (ESP-1000),

- Waste Acceptance Criteria for Radiological Solid Waste Disposal (WMRA-WMPC-203),

- ORNL Liquid Waste Treatment Systems Waste Acceptance Criteria (WM-WMCO-201),

- Waste Item Description (UCN-2109) Form User Instructions,

- Container Packing List (TX-5749) Form User Instructions, and

- Management of Investigation-derived Waste During Site Investigations (EPA 1991).

\subsection{WASTE CHARACTERIZATION/SEGREGATION}

When waste is generated, it will be put into a plastic bag. The bag will be screened by HP to determine its disposition. Table 5.1 shows the various categories into which waste will be segregated for this project, the criteria for segregation, and packaging requirements.

At the end of each day, HP personnel will use portable alpha and beta/gamma detectors to monitor the material removed for the presence of radioactivity. They will designate waste as being "Clean," "Very Low Activity," or "Low Level" Waste. 
Table 5.1. WAG 6 waste management

\begin{tabular}{|c|c|c|c|c|c|}
\hline $\begin{array}{c}\text { Type } \\
\text { of waste }\end{array}$ & $\begin{array}{l}\text { Category } \\
\text { of waste }\end{array}$ & $\begin{array}{l}\text { Segregation } \\
\text { requirements }\end{array}$ & $\begin{array}{c}\text { Packaging } \\
\text { requirements }\end{array}$ & $\begin{array}{l}\text { Accumulation/ } \\
\text { staging area }\end{array}$ & $\begin{array}{c}\text { Final } \\
\text { disposal }^{b}\end{array}$ \\
\hline \multirow[t]{3}{*}{$\begin{array}{l}\text { Miscellaneous trash } \\
\text { (personal protective } \\
\text { equipment, } \\
\text { plastics, paper) }\end{array}$} & 5 & $\begin{array}{l}\text { No } \alpha \text { or } \beta / \gamma \\
\text { no volatiles }\end{array}$ & $\begin{array}{l}\text { Plastic bags in garbage } \\
\text { cans at site }\end{array}$ & $\begin{array}{l}\text { Green dumpster } \\
\text { adjacent to personnel } \\
\text { trailers }\end{array}$ & $Y-12$ landfill \\
\hline & 8 & $\begin{array}{l}\text { Suspected } \alpha \text { or } \beta / \gamma \text { but no } \\
\text { volatiles }\end{array}$ & $\begin{array}{l}\text { Package per Solid } \\
\text { Waste Storage Area } \\
\text { (SWSA) } 6 \text { Waste Area } \\
\text { Criteria instructions } \\
\text { (WMRA-WMPC-203) }\end{array}$ & GCO-designated area & $\begin{array}{l}\text { Site designated by Waste } \\
\text { Management Operations }\end{array}$ \\
\hline & 14 & $\begin{array}{l}\alpha \text { or } \beta / \gamma \\
\text { no volatiles }\end{array}$ & $\begin{array}{l}\text { Package per SWSA } 6 \\
\text { Waste Area Criteria } \\
\text { instructions (WMRA- } \\
\text { WMPC-203) }\end{array}$ & GCO-designated area & SWSA 5-box compactor \\
\hline
\end{tabular}

a Categories of waste as delineated by the Project WMP.

b According to Tables 3.2 and 3.3 in the Project WMP. 
HP personnel will be responsible for scanning all waste entering and leaving WAG 6. If the waste is within Energy Systems standards, the waste will be issued a "green tag," signifying that it is "clean" of radioactive contamination. An on-site dumpster adjacent to personnel trailers will be available for "clean" waste, such as office papers, generated on site.

\subsection{WASTE PACKAgING}

After waste has been characterized and segregated according to category, waste packets can be created. Waste is packaged by the Sample Task Leader according to guidance provided by the GCO. A Waste Item Description Form is filled out for each packet. One bar code label is placed on the waste packet, and the other is placed on the Waste Item Description Form associated with the specific packet. The bar code label number is then copied onto the Container Packing List. When the container is full, the GCO and the Sample Task Leader will complete a Waste Pickup Request Form to be submitted to WMO by the GCO. The Waste Management forms and their instructions for use, as well as waste acceptance criteria, will be located on site in the WAG 6 project trailers.

\subsection{WASTE TRANSPORTATION}

Energy Systems personnel will manage and conduct the transportation of waste to locations outside WAG 6 and the transportation of all liquid waste. 


\section{DATA MANAGEMENT}

\subsection{INTRODUCTION}

The data management team will create "Blank Form Books" filled with previously bar coded forms to be used by the field teams. Each type of form will be stored in a separate book and wili have the bar code pre-attached to the bottom right corner of the form. A copy of the appropriate form will be inserted on the outside cover of the "Blank Form Book," and the binder will signify the form number. The form bar code label will be scanned by the STL entering it into the bar code reader for uploading to the data base when using the form. If that form is not used after being taken to the field, the STL will return the blank form to the notebook for use on another day.

The form bar code numbers must be used in sequence for record keeping purposes. The form bar code numbers will serve as identifiers for location of the forms in the files. When the STL returns to the trailer at the end of the day, the forms will be forwarded to the FTM for review. The DM will receive all completed forms and the data diskette downloaded from the bar code reader on a daily basis. The electronic-data-downloading diskettes downloaded from the monitoring equipment will be forwarded to the DM by the FTM on a monthly basis (and more frequently if necessary).

\subsection{DATA DOWNLOADING}

Field data collected during the WAG 6 Meteorological Monitoring Program will be obtained electronically. Electronic data will be collected by the OMNIDATA Easy Logger and will be downloaded, edited, and screened by the sampling team.

\subsubsection{Electronic Data}

Raw electronic data generated for meteorological monitoring will consist of hourly averages of wind speed, wind direction, humidity, temperature, and solar radiation, and 5-min averages of precipitation activity. Electronic data will be downloaded, edited, screened and gathered into site report files. Data files will be traced, from downloading to archiving and internal verification, on an electronic data file management worksheet. The following guidelines should be followed when manipulating electronic data.

- Download electronic data collected by the OMNIDATA Easy Logger.

- Copy the raw data to a working 3.5-in. high-density (HD) diskette using the extension .93 (or the appropriate year), and to an archival Bernoulli using the extension .93\%. Use the working diskette to "clean up" data. Attach a label to the archival Bernoulli and place in temporary storage. Attach a second label on the working diskette and begin processing.

- Take the working diskette to the site office PC.

- Use a DOS editing tool to combine multiple data sets if they were not joined at the time of data downloading. The precipitation data remain in a separate data set from all other data collected. 
- Use a SAS program to reformat the data and create SAS files containing the original data and additional fields required for data validation.

- Print a tabular report of the data prior to any data corrections [to be submitted as part of the Energy Systems Met Lead (ESML) data validation package].

- Use the SAS editor to fill in missing data points and set appropriate validation flags on adjusted data. Use SAS to produce graphs depicting the "before correction" view of the data sets (to be submitted as part of the ESML data validation package).

- Use the SAS graphs provided for the validation of data to determine abnormal data results. Use the SAS editor to correct any abnormal data values and apply data qualifiers according to the data correction rules provided by the ESML.

- Within 5 working days of data collection, the STL will provide to the ESML tabular and graphical reports reflecting "before and after correction" views of the data sets. Create the transmittal form to accompany the data validation package supplied to the ESML.

- The ESML will review the data validation package and, if further corrections are in order, will inform the STL within 5 working days of the necessary changes. When all corrections have been performed and the ESML is satisfied with the quality of the data, the ESML will sign the transmittal form and return to the STL. The STL will then give the signed form to the DM. When the DM is satisfied that all information delivered is correct, the DM will then take the steps to load the data into the WAG 6 Oracle data base (appropriate data validation flags will be set), sign the form and process the form in accordance with prescribed records management.

\subsection{PROCEDURES FOR COMPLETING METEOROLOGICAL MONITORING (MM) FORMS}

The WAG 6 meteorological monitoring team will be using a bar code reader in the field when available to record most of the information that will be tracked in the WAG 6 project data base. There will be only one monitoring location for the meteorological monitoring process. Therefore, the data base will default that field for entry purposes.

\section{MM-01: WAG 6-METEOROLOGICAL MONITORING INITIALIZATION FORM}

Before leaving the trailer, the STL will pull one form MM-01 for each piece of equipment to be initialized that day. Upon arrival at the site, the STL will scan the project task code and monitoring location from a menu card, the STL badge number, the field logbook number, the form bar code label, and the equipment bar code ID of each piece of equipment to be initialized at that location. The reader will prompt the STL to specify the type of initialization (i.e., new or replacement). If replacement event is chosen, the STL will complete Form RF-01 in accordance with Form RF-01 procedures. The "Comments" field is optional and will not be captured in the reader. If there is anything concerning the event that the STL wants tracked in the data base, the STL will note that information in the "Comments" field of the form. The DM will manually enter the information once the form has been submitted and the field data have been added to the data base. 


\section{MM-02: WAG 6-METEOROLOGICAL SITE INSPECTION/DATA COLIECTION FORM}

Before leaving the trailer, the STL will pull one form MM-02 for each site to be inspected or downloaded. Upon arrival at the site, the STL will scan the project task code from a menu card, sample team's badges (by role), the field logbook number, and the form bar code label. The "Comments" field is optional. If there is anything concerning the event that the STL wants tracked in the data base, the STL will note that information in the "Comments" field of the form. The DM will manually enter the information once the form has been submitted and the field data have been added to the data base.

\section{MM-03: WAG 6-METEOROLOGICAL INSTRUMENT CALIBRATION/FIELD CHECK FORM}

Before leaving the trailer, the STL will pull one form MM-03. Upon arrival at the site, the STL will scan the project task field code, his or her badge number, the field logbook number, the form bar code label, and the equipment bar code ID. If the equipment was temporarily taken out of service, the STL will note that section of the form and send a copy to the DM for entry into the data base. The DM will note the status and will update the data base accordingly. When the equipment is returned, the STL will complete the form and send the original to the DM. The "Comments" field is optional and will not be captured on the reader. If there is anything concerning the event that the STL wants tracked in the data base, the STL will note that information in the "Comments" field of the form. The DM will manually enter the information once the form has been submitted and the field data have been added to the data base. 


\section{REFERENCES}

ASME (American Society of Mechanical Engineers) 1989. Quality Assurance Program Requirements for Nuclear Facilities, ASME NQA-1, New York.

CDM Federal (CDM Federal Programs Corporation) 1993. Quality Assurance Plan for Characterization and Monitoring Activities at Waste Area Grouping 6, Oak Ridge National Laboratory, Oak Ridge, Tennessee.

DOE (U.S. Department of Energy) 1993a. Environmental Monitoring Plan for Waste Area Grouping 6 at Oak Ridge National Laboratory, Oak Ridge, Tennessee, ORNL/ER-158, prepared by Science Applications International Corporation, Oak Ridge, Tennessee, September.

DOE (U.S. Department of Energy) 1993b. Quality Assurance Project Plan for the Environmental Monitoring Program in Waste Area Grouping 6 at Oak Ridge National Laboratory, Oak Ridge, Tennessee. DOE/OR/01-1193\&D1, prepared by Gilbert/Commonwealth, Inc., Oak Ridge National Laboratory, Oak Ridge, Tennessee, September.

Energy Systems (Martin Marietta Energy Systems, Inc.) 1991. Resource Conservation and Recovery Act Facility Investigation Report for Waste Area Grouping 6 at Oak Ridge National Laboratory, Oak Ridge, Tennessee, ES/ER-22/V2\&D1.

Energy Systems (Martin Marietta Ener gy Systems, Inc.) 1993. Environmental Restoration Quality Program Plan, ES/ER/TM-4/R3.

EPA (U.S. Environmental Protection Agency) 1983. Interim Guidelines and Specifications for Preparing Quality Assurance Project Plans, QAMS-005/80, EPA-600/4-83-004. Washington, D.C.

EPA (U.S. Environmental Protection Agency) 1991. Management of Investigation-derived Waste During Site Investigations, EPA/540/G-91/009.

Miller, G. P., K. C. Black, and P. M. Craig 1989. SWSA-6 Interim Correction Measures, Environmental Monitoring Summary Report, ECE-89-017, Oak Ridge National Laboratory, Oak Ridge, Tennessee. 
APPENDIX A

FIELD FORMS 
A-3

WAG 6 - METEOROLOGICAL MONITORING INITIALIZATION FORM (MM-01)

Page 1 of 2

Monitoring Location:

STL Badge No.:

Weather:
Field Logbook Number:

Date:

Time:

\section{EQUIPMENT}

Equipment Bar Code ID:

Now/replacement Installation: Old Bar Code ID:

Date of most recent calibration:

Wiring Channel Number

Channel Name

Sensor Name

Sensor Formula(s)

Scan Interval

Report Interval

Report Number

\section{EASY LOCGER FID UNT}

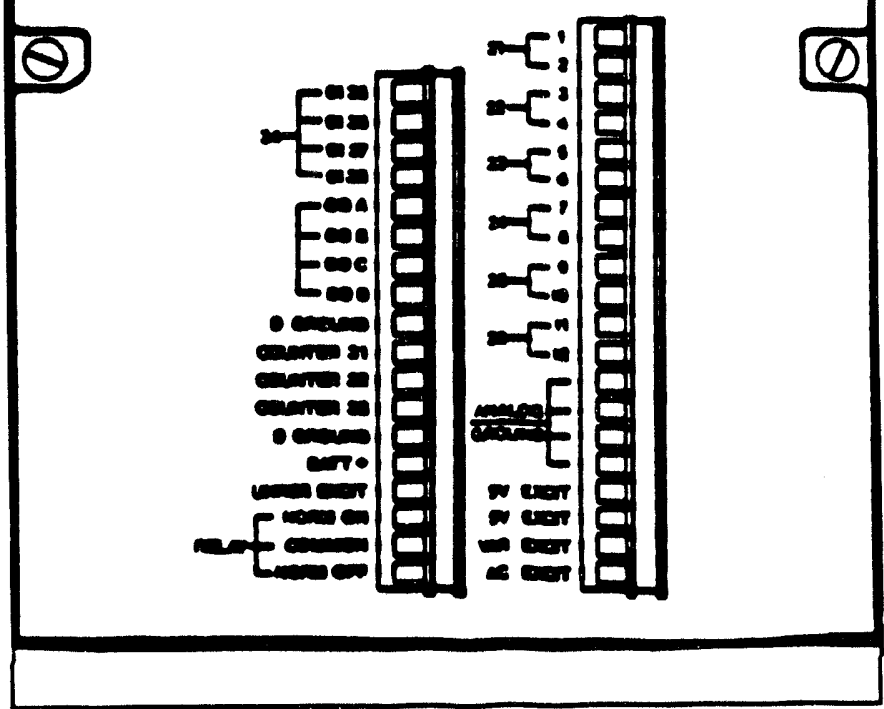

Indicate wiring on above diagram. Write wire color next to port.

Comments:

EASY LOGGER Bar Code ID:

New or Replacement Installation:

Old Bar Code ID:

Checklist: Lithium Backup Battery Test Batteries (option 32) $\mathrm{V}$ (must be $>10.5 \mathrm{~V}$ )

Dessicant Replaced Wiring Connected/Checked Set Clock (option 20) Set Sensors (option 12) Set Wiring (option 13) Set Scantime (option 14) Set Functions? (option 22) Functions

Set Reports (option 15)

(fill out report table on next page)

No. of DSP Installed 
(NOTE: Give a description of the programming objectives on the back of this page)

\begin{tabular}{||l|c|c|c|c|c||}
\hline \multicolumn{3}{||l|}{ REPORT TABLE (Option 15) } \\
\hline REPORT \# & C1 & C2 & C3 & C4 & C5 \\
\hline COLUMN \# & & & & & \\
\hline \hline 1st HEADING & & & & & \\
\hline 2nd HEADING & & & & & \\
\hline UNITS & & & & & \\
\hline $\begin{array}{l}\text { DATA SOURCE } \\
\text { (CHANNEL NAME) }\end{array}$ & & & & & \\
\hline TYPE & & & & & \\
\hline DECIMAL & & & & & \\
\hline
\end{tabular}

Comments:

Sample Task Leader (Signature/Date):

Data Entry (Signature/Date):

Data Verification (Signature/Date): 


\section{WAG 6 - METEOROLOGICAL SITE INSPECTION/DATA COLLECTION FORM (MM-02)}

Monitoring Location:

Field Logbook Number:

STL Badge No.:

Date:

Time:

Weather Conditions:

INSPECTION (do not stop logging)

Clean debris from tipping bucket rain gauge screen

Check dessicant: If pink, replace

Checked/changed? $\quad \mathrm{Y} / \mathrm{N}$

Logging? $\quad \mathrm{Y} / \mathrm{N}$

Show Data (option 40)

Logger Battery Voltage (Option 32) V New battery? (if $<10.5 \mathrm{~V}$ ) $\quad \mathrm{Y} / \mathrm{N}$

Show DSP Status (Option 41) $\%$

Show Clock (Option 20) EST (time cannot be changed while logging)

Recording Last Reported Value? Y/N

Air Flow LCA6000 Equipment ID:

Psychrometer Equipment ID:

Last Recorded Value

\begin{tabular}{|l|l|l|l|l|l|l||}
\hline Sensor/Instrument & Wind Speed & Wind Dir. & Air Temp. & Rel. Hum. & Sol. Rad. & Rainfall \\
\hline Reported Value & & & & & & \\
\hline
\end{tabular}

Comments:

\section{Data Collection}

Note: do not remove black strap from DSP

Time logging was stopped (EST) Time logging was started

Retrieved DSP No.: Installed DSP No.:

Comments:

Sample Task Leader (Signature/Date):

Data Entry (Signature/Date):

Data Verification (Signature/Date):

Form Bar Code Label

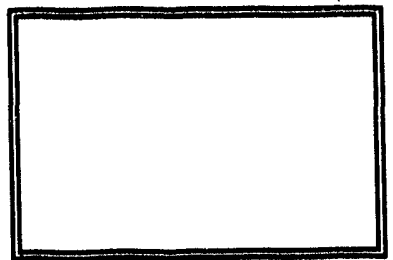




\section{WAG 6 - METEOROLOGICAL INSTRUMENT CALIBRATION/FIELD CHECK FORM (MM-03)}

Monitoring Location:

STL Badge No.:
Field Logbook Number:

Date:

Time:

Weather:

Instrument (circle):

pyranometer

rain gauge

temp/rel.humidity

wind speed/direction

Equipment Bar Code ID:

\section{FIFLD CALIBRATION CHECK}

As found (Easy Logger reading)

Calibration Check Method

Comparison Value:

Percent Difference:

Comments/Action Taken:

\section{INSTRUMENTATION AND CONTROLS CALIBRATION}

Time \& Date Out of Service:

I\&C Calibration Date:

Time \& Date Returned:

Date Next Calibration Needed:

Comments:

Form Bar Code Label

Sample Task Leader (Signature/Date):

Data Entry (Signature/Date):

Data Verification (Signature/Date):

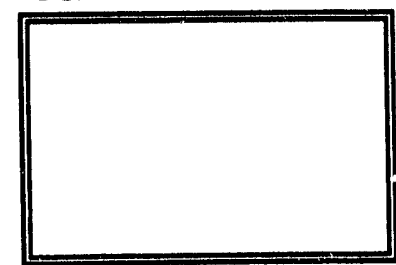




\section{WAG 6 - MONTTORING VARIANCE REQUEST FORM (MV-01)}

(Once completed, insert this form into site notebook. If more than one site is affected, insert a copy of this form into all appropriate notebooks.)

\section{Matrix:}

ID of affected site(s):

Name and title of person making request:

Date:

Document very specifically the variance being requested. Be sure to identify all pertinent Data Quality Objectives that are affected by this variance:

Document the reasons for requesting the variance:

Document the time scale of the variance. Include dates at which this variance will start and end (if applicable):

Variance approval signature: STL:

Date:

FTM:

Date:

WAG 6 Project Manager:

Date:

Form Bar Code Label

Data entry signature/date:

Data verification signature/date:

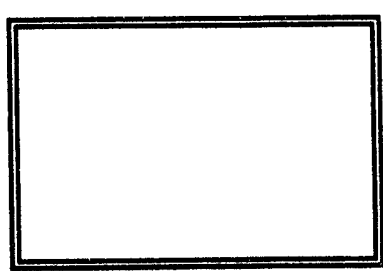


WAG 6 - RECORD OF REPAIR FORM (RF-01)

DATE:

EMPLOYEE BADGE NO.:

EQUIPMENT BAR CODE NO.:

EQUIPMENT STATUS: IN-USE (circle one)

AVAILABLE

Disposition of unit:

Comments:

Was damage discovered during routine site inspection? Yes No

If yes, list inspection form number or logbook number.

Nature of damage if known: Date found:

Was unit repairable in situ? Yes No

If yes, list repairs made and person making them.

Did in situ repairs include replacing any parts/accessories? Yes No

If yes, list and describe.

Was equipment sent to offsite vendor for repair? Yes No If yes, list:

Vendor: Address:

Airbill No. (if shipped):

Work Order No:

Date Sent:

Initial:

Date returned:

Received by:

Type of repair:

Was unit returned in good working condition? Yes / No

If no, please describe:

Returned Equipment Status:

Sample Task Leader Signature/Date:

Data Entry Signature/Date:

Data Verification Signature/Date:

Form Bar Code Label

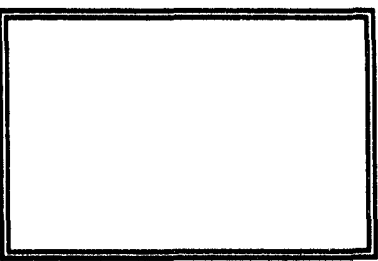




\section{APPENDIX B}

\section{SITE-SPECIFIC HAZARD EVALUATION ADDENDUM FOR WAG 6 METEOROLOGICAL MONITORING}


SITE-SPECIFIC HAZARD EVALUATION ADDENDUM FOR WAG 6 METEOROLOGICAL MONITORING

$5 D V G$ laos 12100153

S. $\Gamma$. Van Hoesen

ER WAG 6 Project Manager
B.f.Mlogen $12 / 44 / 93$

B. L. Morgan

ORNL Construction Engineer

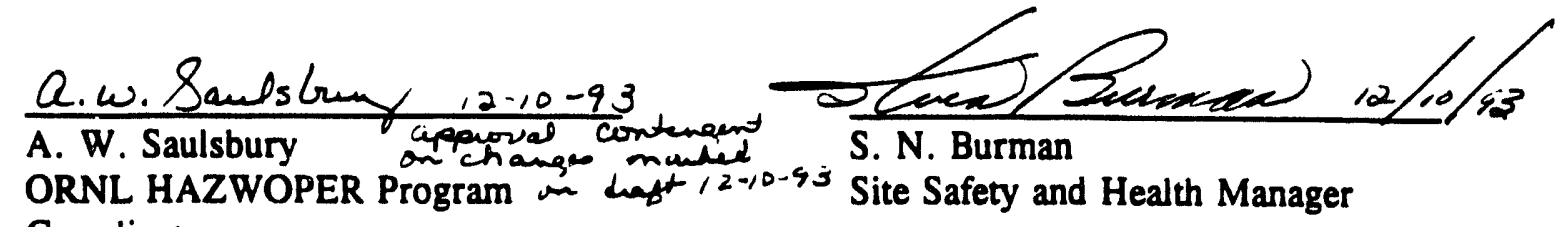

Coordinator

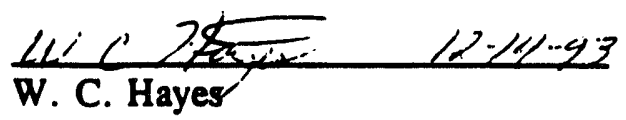

ORNL Applied Health Physicist

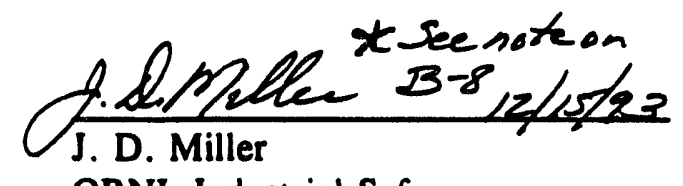

ORNL Industrial Safely

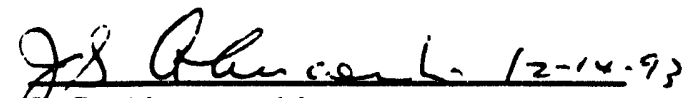

G. S. Abercrombie Laboratory Protgation

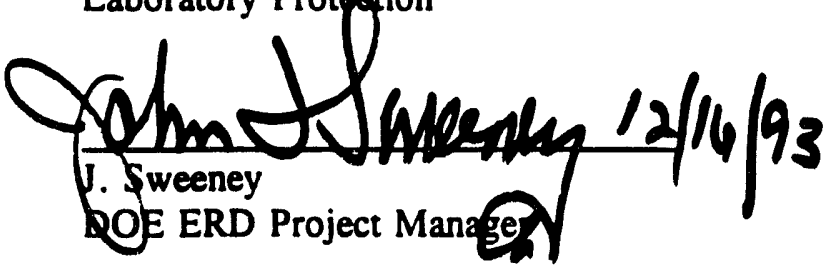

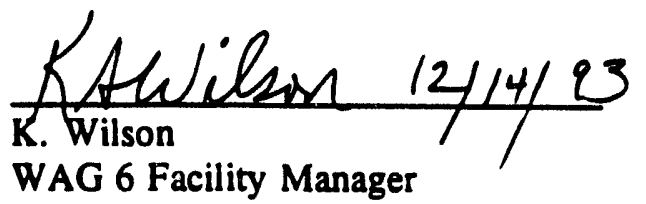

margarito later $12 / 16 / 93$ M. M. Slater

ORNL IH Construction Oversight

Chelaclain 12/10\%?

C. Clark, Jr.

Environmental Restoration Office 


\section{SITE-SPECIFIC HAZARD EVALUATION ADDENDUM FOR WAG 6 METEOROLOGICAL MONITORING}

This Site-specific Hazard Evaluation Addendum is for the performance of the Waste Area Grouping (WAG) 6 meteorological monitoring. The work will be conducted by CDM Federal Programs Corporation (CDM Federal) and associated Oak Ridge National Laboratory (ORNL) environmental, safety, and health support groups. This activity will fall under the scope of 29 CFR 1910.120, Hazardous Waste Operations and Emergency Response (HAZWOPER). The purpose of this document is to establish site-specific health and safety guidelines to be folluwed by all personnel involved in conducting work for this project. Work will be conducted in accordance with requirements as stipulated in the ORNL HAZWOPER Program Manual and applicable ORNL, Martin Marietta Energy Systems, Inc., and U.S. Department of Energy policies and procedures. The Environmental (Site) Safety and Health Plan (SSHP) serves as an extension of the ORNL HAZWOPER Program Manual; combined, they fulfill the requirements of 29 CFR 1910.120.

The levels of protection and the procedures specified in this plan are based on the best information available from historical data and preliminary evaluations of the area. Therefore, these recommendations represent the minimum health and safety requirements to be observed by all personnel engaged in this project. Unforeseeable site conditions, changes in scope of work, or hazardous conditions not previously considered will warrant a reassessment of protection levels and controls stated. Minor changes, such as downgrade of personal protective equipment (PPE) or change in the model of a site instrument, may be justified and documented in the site logbook by the Site Safety and Health Officer (SSHO). Significant changes will require revision of the SSHP and must have approval by the appropriate safety and health discipline and the HAZWOPER Program Coordinator (HPC) before restart of site operations. 


\section{PROJECT AND SITE DESCRIPTION}

\subsection{PROJECT DESCRIPTION}

The meteorological data that will be collected include wind speed and direction, dry bulb temperature, relative humidity, solar radiation, and precipitation. These parameters will be monitored at the Tumulus Meteorology Station located south of the Tumulus $1 \mathrm{Pad}$ and will be sampled continuously using an OMNIDATA Easy Logger equipped with a 32K EPROM Data Storage Pack. The instructions and guidelines for retrieving the DSP and processing the data are located in Sect. 2 of the Meteorological Monitoring Sampling and Analysis Plan. The following figure, taken from the sampling and analysis plan, shows the location of the meteorological monitoring station.

\subsection{SITE DESCRIPTION}

Information regarding the WAG 6 site description can be found in the Draft RCRA Facility Investigation Report for Waste Area Grouping 6 at Oak Ridge National Laboratory, Oak Ridge, Tennessee, ES/ER-22/V2\&D1 (Energy Systems, September 1991). 


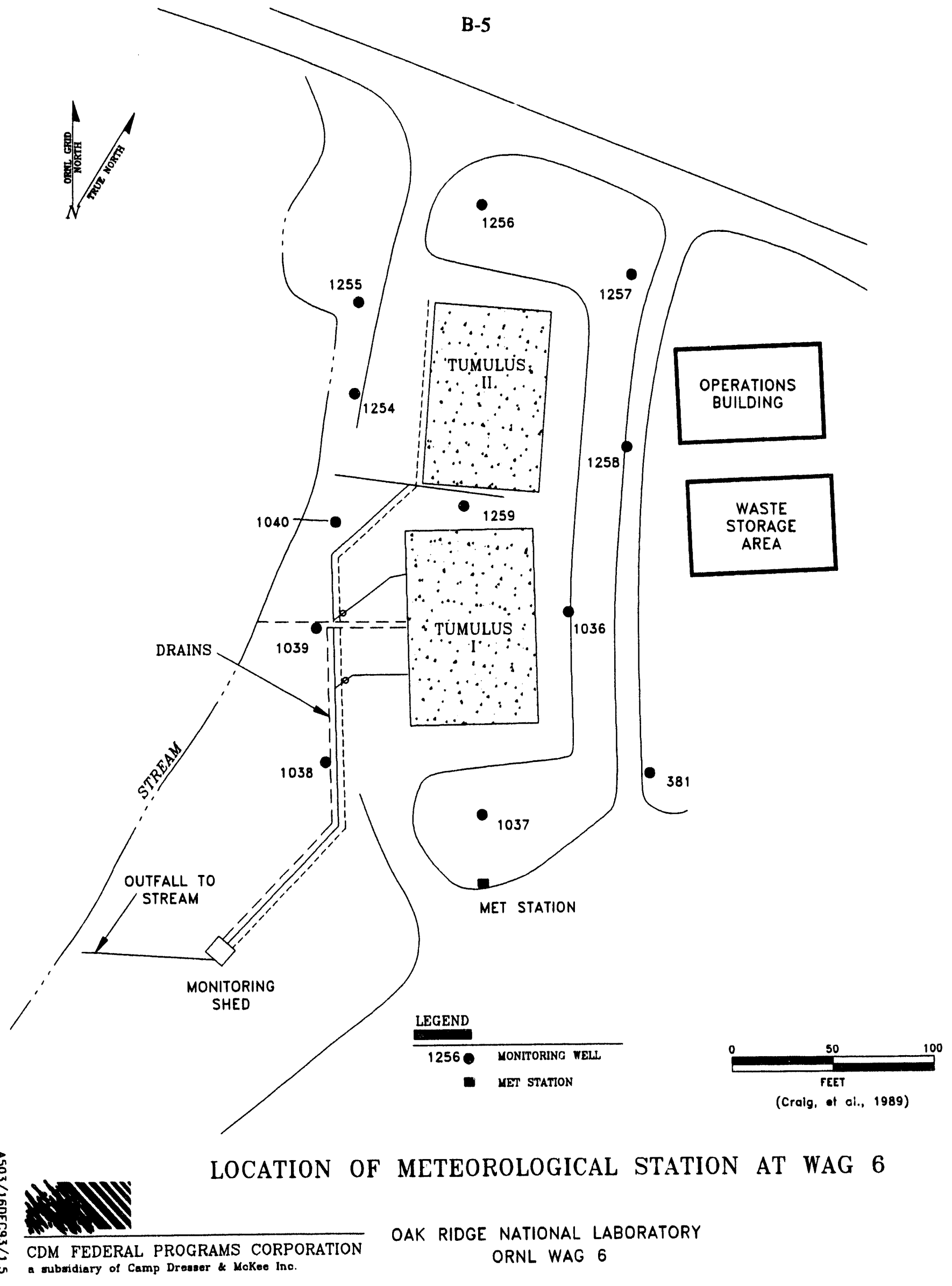




\section{SITE ORGANIZATION AND COORDINATION}

The work will be performed by CDM Federal. ORNL Industrial Hygiene (IH), Industrial Safety (IS), and Radiation Protection (RP) will provide appropriate health and safety services oversight.

The following section details the organizational structure for this project. Key personnel and their project responsibilities are listed. Measurement Applications \& Development will serve as the Site Safety and Health Officer (SSHO) and alternate SSHO.

\subsection{SITE SAFETY AND HEALTH OFFICER}

The SSHO is the primary on-site contact for safety and health during field activities. The SSHO oversees the on-site execution of all field activities regarding safety and health procedures, and has the authority to stop all work if conditions are judged to be hazardous to on-site personnel or to the public. The SSHO will remain at the project site at all times while workers are performing site activities. Other specific responsibilities are as follows.

1. Ensures that all on-site project personnel meet the required level of training, meet medical requirements including respirator fit test (as required), attend a pre-entry briefing on project and potential site hazards, and review the Work Plan and SSHP. Maintains copies of documentation of the above at the project site and ensures that documentation is available for on-site review. Note: The ORNL Special Access Training Badge may be used as verification of training.

2. Requires personnel to obtain immediate medical attention in the case of a work-related injury or illness.

3. Denies access to all or any portion of the work area as warranted.

4. Orders work to cease, orders evacuation of the work area by all personnel, and reestablishes safe working conditions, as needed.

5. Controls access to the site by visitors and unauthorized personnel. Advises visitors and unauthorized personnel of their responsibilities and ensures that they meet access requirements before entry into the contamination reduction zone or exclusion zone is allowed.

6. Ensures the correct field execution of the Work Plan and SSHP.

7. Ensures that this Work Plan and SSHP are revised and approved if there are changes in site conditions or tasks.

8. Advises emergency response personnel in an emergency.

9. Coordinates with IH, IS, and RP to establish site work zones, level of required personnel protection, monitoring, and other controls. 
10. Coordinates and minimizes the number of personnel and amount of equipment in the work zones.

11. Coordinates accident prevention by oversight of field activities and by being aware of all site operations.

12. Ensures that needed work permits are obtained and made available on site.

13. Ensures that the HPC, IH, IS, and RP are contacted before commencement of site work (1) to notify of intent to begin work and (2) to schedule monitoring support, as needed.

14. Conducts daily inspection of the work site.

15. Provides the HPC with a list of personnel participating in site activities to determine the need for inclusion in the hazardous-waste-worker medical surveillance program.

16. Ensures that appropriate fall protection measures are in place, as warranted.

17. Ensures that an approved hoisting and rigging plan is available, as warranted.

18. Ensures that appropriate measure have been taken to prevent spills.

\subsection{FIELD PERSONNEL}

Specific responsibilities are as follows.

1. Take all reasonable precautions to prevent injury to themselves and to their fellow employees; be alert to potentially harmful situations.

2. Perform only those tasks that they believe they can do safely and immediately reporting any accidents and/or unsafe conditions to the SSHO.

3. Notify the SSHO of any special medical conditions (e.g., allergies, diabetes).

4. Prevent spills to the extent possible. If spills occur, contain the spill, notify the SSHO, and clean up immediately using safe cleanup measures as directed by the SSHO. Note: Do not engage in spill containment or cleanup if conditions are not safe and if the cleanup cannot be accomplished with supplies available at the site. Evacuate the area. All spills must be reported to the ORNL Environmental Inte:face (574-8770).

5. Avoid splashing materials to the extent possible.

6. Practice good housekeeping by keeping the work area neat, clean, and orderly to the extent possible.

7. Report all injuries, no matter how minor.

8. Comply with the work plan and SSHP as well as with postings and rules at the project site. 


\subsection{RADIATION PROTECTION (Jim Ed Irwin)}

ORNL Radiation Protection will be responsible for oversight and approval of personnel protection requirements related to radiation protection. A representative from the Office of Radiation Protection will review and approve the Work Plan and SSHP before commencement of field activities. ORNL RP will be consulted before entry into any posted radiological area and will instruct field participants on requirements for that area, including the need for a Radiation Work Permit, appropriate monitoring, dosimetry, and PPE. The RP representative will be contacted for all radiological concerns at the site.

\subsection{INDUSTRIAL HYGIENE (Margaret Slater)}

The ORNL Industrial Hygiene Section and the HPC will be responsible for the oversight and approval of personnel protection related to IH and the requirements of 29 CFR 1910.120 (HAZWOPER). The IH Divisional Representative and the HPC will review and approve the Work Plan and SSHP before commencement of field activities. The IH representative and the HPC will provide guidance regarding PPE and IH monitoring and sampling requirements. The IH Section will be contacted for all industrial hygiene and HAZWOPER concerns at the site.

\subsection{INDUSTRIAL SAFETY (Doug Miller)}

The ORNL Industrial Safety Section will be responsible for oversight and approval of personnel protection related to safety. A representative from IS will review and approve the Work Plan and SSHP before commencement of field activities. IS will provide guidance regarding potential safety hazards, PPE and safety requirements. The IS Section representative will be contacted for all safety concerns at the site.

A complete organizational structure and description of resposibilities may be found in Sect. 3 of the SSHP. 


\section{PROJECT HAZARD EVALUATION}

Task: Meteorological monitoring

The meteorological monitoring task has no physical hazards, safety/construction hazards, chemical hazards, ionizing or non-ionizating radiation hazards, or biological hazards associated with it.

\subsection{PHYSICAL haZARDS}
( ) Heat stress
( ) Cold stress
( ) Noise
( ) Confined space
( ) Enclosed space
( ) Manual lifting
( ) Tripping/falling
( ) Ergonomic
( ) High pressure
( ) Oxygen deficient
( ) Explosives/flammables
( ) Vibration

\subsection{SAFETY/CONSTRUCTION HAZARDS}
( ) Trenching
( ) Excavating
( ) Heavy equipment operation
( ) Demolition
( ) Elevated work
( ) Welding/cutting
( ) Hoisting/rigging
( ) Underground hazards
( ) Overhead hazards

\subsection{CHEMICAL HAZARDS}
( ) Volatile organics
( ) Inorganics
( ) Carcinogens
( ) Corrosives
( ) Reproductive toxicants
( ) Metals
( ) Mutagens
( ) Asbestos
( ) OSHA specific

\subsection{IONIZING RADIOLOGICAL HAZARDS}
( ) Internal exposure
( ) External exposure

\subsection{NON-IONIZING RADIOLOGICAL HAZARDS}
( ) UV
( ) $\mathbf{R F}$
( ) Laser
( ) High voltage
( ) Microwave

\subsection{BIOLOGICAL/VECTOR HAZARDS}
( ) Wildlife
( ) Plants
( ) Medical waste
( ) Bacteria
( ) Parasites 


\subsection{DESCRIPTION OF HAZARDS AND CONTROLS}

\subsubsection{Sanitation}

Task: Meteorological monitoring

A clean zone located on WAG 6 provides workers with an eating area, toilet facilities, washing facilities (hand wash and emergency eye wash only), and a changing room.

Potable water required? Not permitted on work site

Nonpotable water used? None

Eating, drinking, chewing, use of tobacco permitted?

Location: As stated above.

Toilet facilities required?

Location and number: As stated above. Available in WAG 6

Washing facilities required?

Location: As stated above.

Change rooms required?

Specify: As stated above.

\subsubsection{Illumination}

Task: Meteorological monitoring

Additional illumination needed? ( ) Yes (X) No ( ) NA

All field activities will be performed during daylight hours. No additional illumination will be required. 


\section{TASK BREAKDOWN}

\subsection{TASK DESCRIPTION}

Task: Meteorological monitoring

Type of Work: ( ) Intrusive (X) Nonintrusive

Engineering Controls: N/A

Administrative Controls (e.g., required permits, training): Training required for meteorological monitoring can be found in the WAG 6 Training Program.

\subsection{INITIAL LEVEL OF PERSONAL PROTECTTVE EQUIPMENT}

Level of Protection: $\begin{array}{llllll}\text { ( ) A } & \text { ( ) B } & \text { ( ) C } & \text { (X) D } & \text { (X) Modified }\end{array}$

Respirator: ( ) SCBA ( ) Full-face ( ) Half-face respirator

( ) PAPR ( ) Other

Cartridge:

Protective Clothing: ( ) Encapsulating suit

(X) Tyvek [if upgraded]

( ) Saranex

( ) Splash suit

( ) C-zone

(X) Company clothing (khakis)

( ) Other

Head/eye/ear:

( ) Hard hat

( ) Splash shield

( ) Other
(X) Safety glasses

( ) Ear plugs

( ) Goggles

( ) Ear muffs

Gloves: ( ) Nitrile

( ) Latex

( ) Neoprene

( ) Vinyl

( ) PVC

( ) Other

Footwear: (X) Steel-toed leather

( ) Chemical overboots

( ) Steel-toed rubber

( ) Other 
B-12

Describe the donning/doffing steps:

Donning and doffing procedures can be found in Sect. 5 of the SSHP: no additional requirements are warranted.

Modifications allowed:

All upgrades of PPE must be approved by the SSHO and by the appropriate safety and health representative, Downgrades in PPE will be justified and documented in the site logbook by the SSHO.

Additional PPE information may be found in Sect. 8 of the SSHP. 


\section{MONITORING REQUIREMENTS}

\subsection{DIRECT READING INSTRUMENTS}

$$
\begin{array}{ccc}
\text { Task(s) } & \begin{array}{c}
\text { Monitoring } \\
\text { Frequency }
\end{array} & \begin{array}{c}
\text { Action } \\
\text { Guidelines }
\end{array}
\end{array}
$$

LEL meter

$\mathrm{O}_{2}$ meter

Colorimetric indicator tubes

Photoionization detector (PID)

Flame ionization detector (FID)

Alpha meter

Beta/gamma meter

Area radiation monitors

Noise meter

Other (Specify)

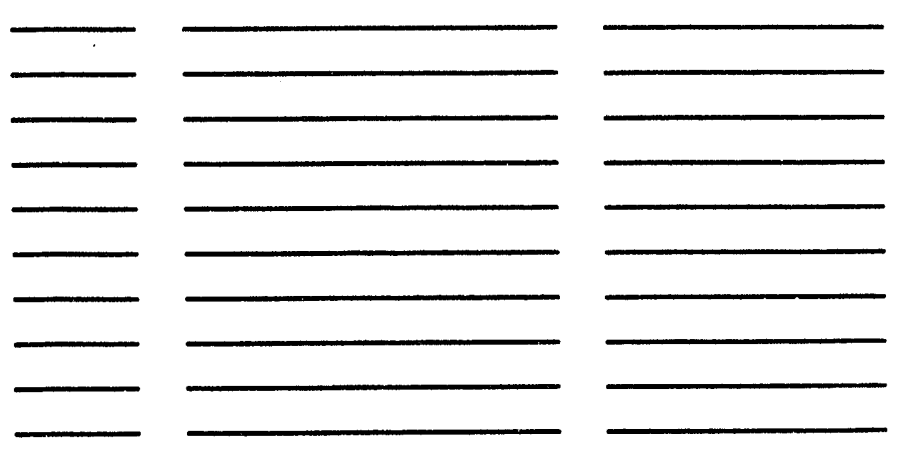

\subsection{PERSONAL MONITORING}

Task(s)

Monitoring

Frequency

$\frac{\frac{M E T}{N A}}{\frac{M E T}{M E T}} \frac{-N A}{\frac{N A}{N A}}$
Action Guidelines

Whole-body dosimetry

Extremity dosimetry

Whole-body count

Urinalysis/bioassay

Chemical air sampling

Radiation air sampling

Personal sampling pumps

Continuously

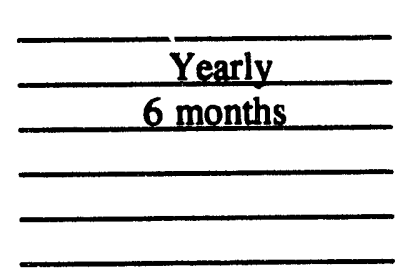

Contact HP

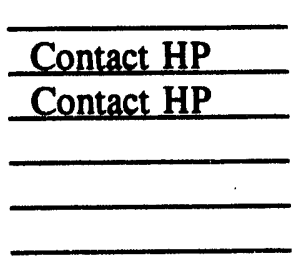

Instruments used by the IH representative will be calibrated and maintained in accordance with IH Standard Operating Procedures. Instruments used by $t^{2}$, Uffice of Radiation Protection are calibrated and source-checked in accordance with established Health Physics procedures.

Site monitoring requirements may change based on site conditions. All changes must be documented in the site logbook. 


\section{SITE CONTROL}

Site work zones are required to reduce the accidental spread of hazardous substances from contaminated areas to clean areas. In accordance with the ORNL HAZWOPER Program Manual, three zones will be established: (1) the exclusion zone, (2) the contamination reduction zone, and (3) the support zone. The identification of the zones will provide for control of operations and flow of personnel. The HPC will provide signs to be posted at the site for HAZWOPER requirements. The HP will determine radiological postings. Should additional barriers (e.g., rope, tape) or signs be required, HP, IH, and IS will be consulted. The HPC may modify the zones for short-term, transient-type projects. The modification would include use of the HAZWOPER barrier tape or A-frame sign only. Additional information regarding site control may be found in Sect. 7 of the ORNL HAZWOPER Program Manual.

Personnel accessing the zones must meet access requirements as stated in this plan and at the entrance of the zones. Entrance and exit points for the zones will be clearly marked. Perimeter monitoring of the zones will be conducted periodically to ensure correct placement of the zones. The SSHO is responsible for ensuring that all workers and visitors meet site access requirements. Section 9 is a record of site access requirements and personnel qualifications.

A site map is provided at the end of this section that includes the assembly point locations and emergency evacuation routes. 


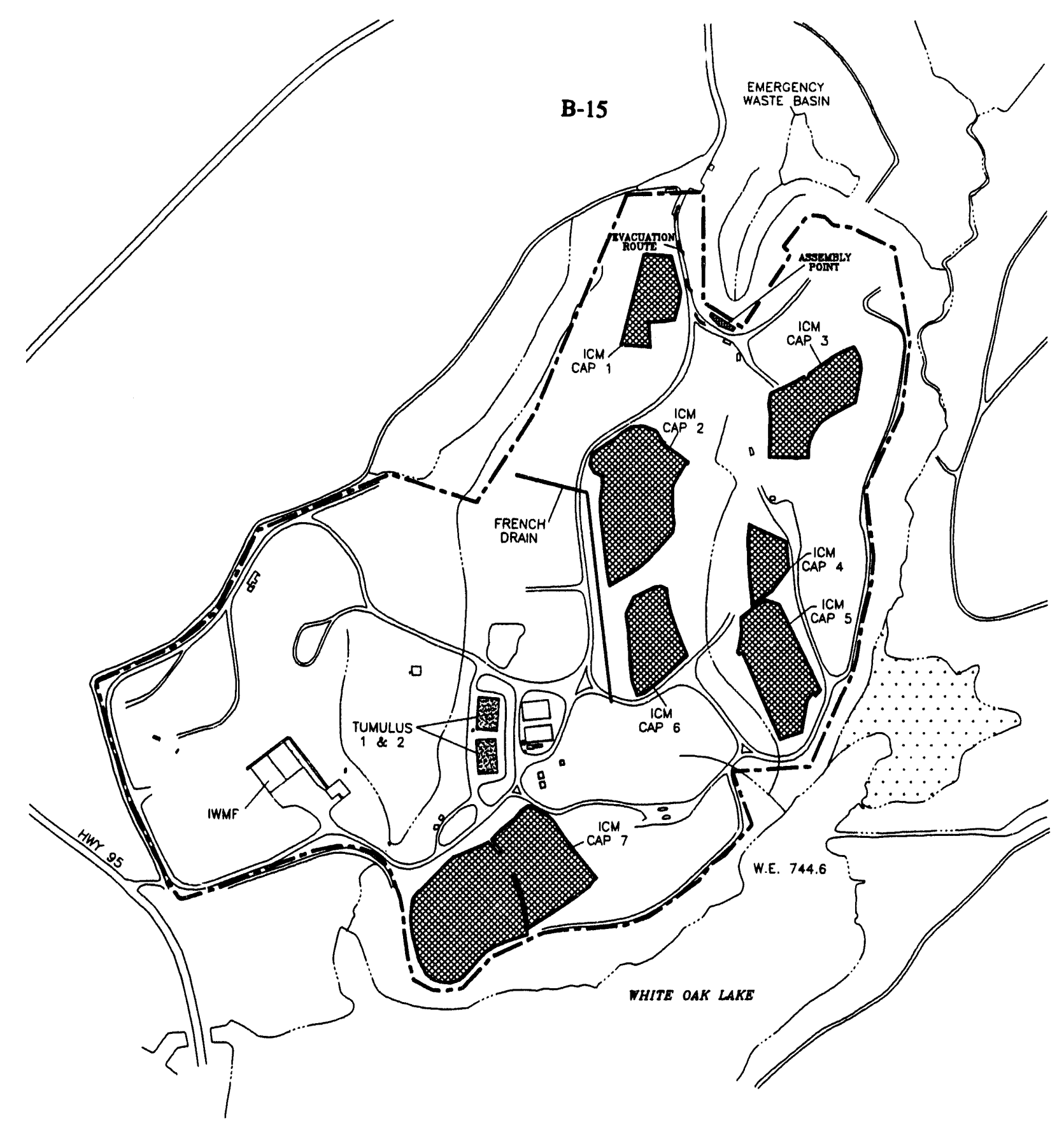

LEGEND
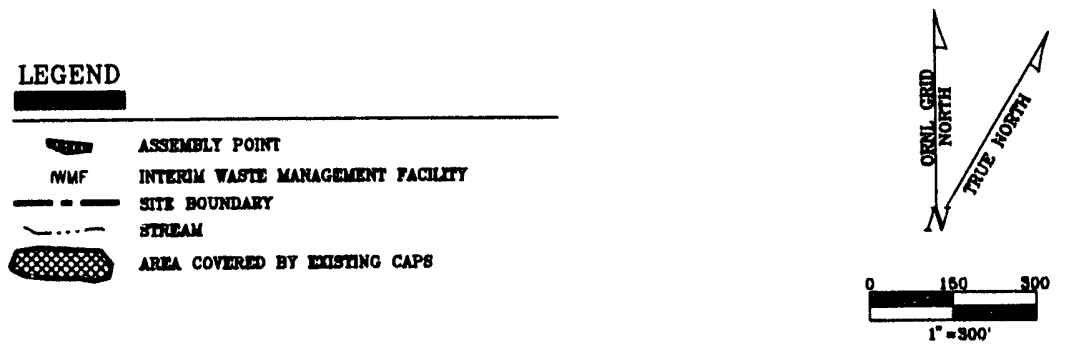


\section{B-16}

\section{DECONTAMINATION}

The purpose of decontamination is to prevent contaminants that may be present on protective clothing and equipment from coming into contact with personnel as they doff PPE. Also, decontamination protects workers from hazardous substances that may contaminate and eventually permeate the PPE used on site; it protects personnel by minimizing the transfer of harmful materials into clean areas. Combining decontamination with the correct sequential method of removing personal protective equipment will prevent exposure to personnel leaving the work areas as well as off-site migration of contaminants. Generally, decontamination is accomplished by starting with the most heavily contaminated item and progressing to the least contaminated item.

Personnel will remove any disposable PPE and dispose of it in provided containers before leaving the contamination reduction zone. The steps for doffing and disposal of PPE can be found in Sect. 5 of the SSHP.

Equipment decontamination will not be required for this task. 


\section{EMERGENCY PREPAREDNESS}

The responsibility for day-to-day implementation of this information lies primarily with tr SSHO. During an actual emergency response situation, the SSHO will serve as the Emergency Coordinator until the Laboratory Shift Superintendent (LSS) or emergency response team arrives.

Medical assistance will be provided by the Health Division, which is located at Building $4500 \mathrm{~N}$. The LSS will provide emergency response personnel and coordinate emergency assistance. The radio number for the LSS is Station 295. The telephone number for the LSS is 574-6606. The nearest telephone and fire alarm box is located at the tumulus site. In the event that the LSS is not available, emergency services may be reached at the telephone numbers shown below.

The SSHO will perform the following pre-emergency tasks before starting field activities and will coordinate emergency response with the LSS.

1. Locate nearest telephone and alarm station.

2. Confirm and post emergency telephone numbers.

3. Post site map of work areas marked with evacuation routes.

4. Inventory and check out on-site emergency equipment and supplies, as warranted.

In the event of an emergency, a fire extinguisher, medical kit, and er argency eyc wash kit are located in the CDM Federal vehicles and in the clean zone. In addition, spill control kits may be found in the permanent decontamination area located outside the clean zone.

In the event of an emergency that requires evacuation of the site, verbal instruction will be given by the SSHO to evacuate the area. Personnel will exit to a predesignated support area. At this point, the SSHO will account for all personnel, ascertain information about the emergency, and give further instructions to the on-site personnel. In all situations that require evacuation, personnel shall not reenter the work area until the conditions causing the emergency have been corrected; the hazard reassessed; the Work Plan and SSHP revised, approved, and reviewed with on-site personnel; and instructions given for reentry.

$\begin{array}{lll}\text { Emergency Personnel } & \text { Phone } & \text { Radio \# } \\ \text { ORNL Emergency Response } & \mathbf{9 1 1} & \\ \text { Laboratory Shift Superintendent } & \mathbf{5 7 4 - 6 6 0 6} & 295 \\ \text { Fire Department } & 574-5678 & \\ \text { Medical Center } & 574-7431 & \\ \text { Security } & 574-7199 & \\ \text { Industrial Hygiene } & 576-7059 & \\ \text { Industrial Safety } & 574-6679 & \\ \text { Radiation Protection } & 599-1338 & \\ \text { Environmental Compliance } & 574-7294 & \\ \text { Emergency Communication Center } & 574-6646 & 295\end{array}$

The SSHO will brief workers on emergency response procedures and the evacuation route in the pre-entry briefing. 


\section{TRAINING/MEDICAL SURVEILLANCE REQUIREMENTS}

List applicable training/medical requirements for this project. All site personnel and visitors requiring access to the work zones (both contamination reduction zone and exclusion zone) will be required to meet these access requirements.

\subsection{PROJECT TRAINING/MEDICAL SURVEILLANCE REQUIREMENTS}

\section{Training}

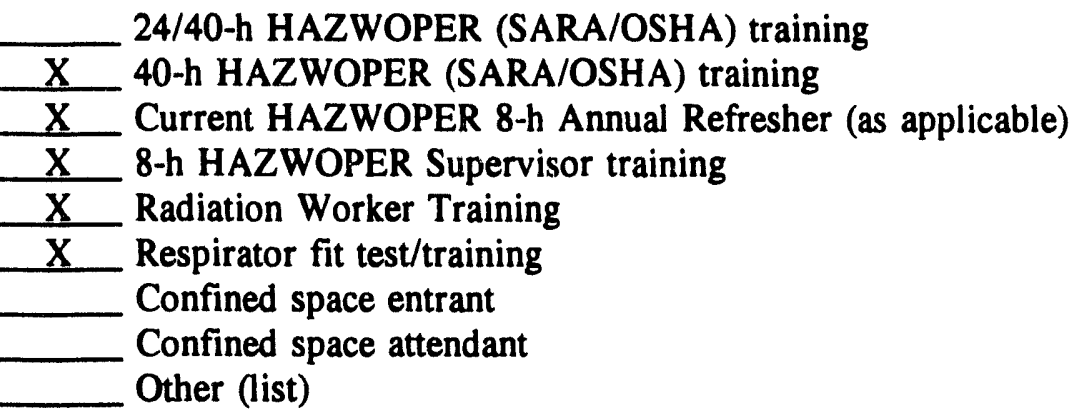

Medical Surveillance

ORNL Hazardous Waste Worker Medical Surveillance Program (only for individual meeting criteria as specified in Sect. 9 of the ORNL HAZWOPER Program Manual).

$\mathrm{X}$ Other: Yearly physical

Note: If site conditions change or if other hazards are detected, the training and access requirements will be revised accordingly.

\subsection{SITE PERSONNEL QUALIFICATIONS}

Name: Patrick Gerbic

Badge number: 626002

Assigned tasks: Meteorological monitoring

\begin{tabular}{|c|c|c|c|}
\hline & $\underline{Y E S}$ & $\underline{\mathrm{NO}}$ & DATE \\
\hline 40-h training: & $\overline{(X)}$ & () & $8 / 93$ \\
\hline 24-h training: & () & () & NA \\
\hline Annual Refresher Training: & () & () & NA \\
\hline Supervisor Training: & $(\mathrm{X})$ & () & $10 / 93$ \\
\hline Confined Space Entry Training: & ( ) & () & NA \\
\hline Radiation Worker Training: & $(\mathrm{X})$ & () & $9 / 93$ \\
\hline Respirator fit tested/trained: & $(\mathrm{X})$ & () & $8 / 93$ \\
\hline Medical Surveillance Program: & $(\mathrm{X})$ & () & $8 / 93$ \\
\hline
\end{tabular}


B-19

Other training: General Employee Training (GET). Satellite Accumulation. RCRA Cap Access. Waste Generator. Hazardous Waste Characterization 


\section{CONTROLLED DISTRIBUTION}

1. T. S. Ball

2. H. L. Boston

3. S. N. Burman

4. R. B. Clapp

5. D. E. Clark

6. G. R. Moline

7. P. A. Schrandt

8. M. M. Stevens

9. D. D. Van Hoesen

10. D. R. Watkins

11. C. L. Callis, CDM Federal Programs Corporation, 800 Oak Ridge Turnpike, Suite 500, Oak Ridge, TN 37830

12. Mike Charko, CDM Federal Programs Corporation, 800 Oak Ridge Turnpike, Suite 500, Oak Ridge, TN 37830

13. David Fugate, PEER Consultants, P.C., 575 Oak Ridge Turnpike, Oak Ridge, TN 37830

14. Patrick Gerbic, PEER Consultants, P.C., 575 Oak Ridge Turnpike, Oak Ridge, TN 37830

15. Doug Hopper, PEER Consultants, P.C., 575 Oak Ridge Turnpike, Oak Ridge, TN 37830

16. Pete Leslie, SAIC, 800 Oak Ridge Turnpike, P.O. Box 5202, Oak Ridge, TN 37830

17. Donnie McCurry, CDM Federal Programs Corporation, 800 Oak Ridge Turnpike, Suite 500, Oak Ridge, TN 37830

18. Richard Stout, PEER, Inc., 575 Oak Ridge Turnpike, Oak Ridge, TN 37830

\section{UNCONTROLIED DISTRIBUTION}

19. H. L. Boston

20. S. E. Childs

21. C. D. Goins

22. R. B. Knott

23-25. D. M. Matteo

26-27. P. T. Owen

28. G. J. Pardue

29. D. J. Pridmore

30. J. H. Stout

31. K. A. Wilson

32. P. S. Wood

33-35. ORNL ER Document Management Center

36-38. Central ER Document Management Center

39. Laboratory Records Department

40. John Jones, Gilbert/Commonwealth, Inc., Suite 200, 1055 Commerce Park Drive, Oak Ridge, TN 37830

41-42. R. C. Sleeman, DOE Oak Ridge Operations Office, P.O. Box 2001, Oak Ridge, TN 378318541

43-44. J. T. Sweeney, DOE Oak Ridge Operations Office, P.O. Box 2001, Oak Ridge, TN 378318541

45. Office of Assistant Manager for Energy Research and Development, DOE Oak Ridge Operations Office, P.O. Box 2001, Oak Ridge, TN 37831-8600

46-47. Office of Scientific and Technical Information, P.O. Box 62, Oak Ridge, TN 37831 

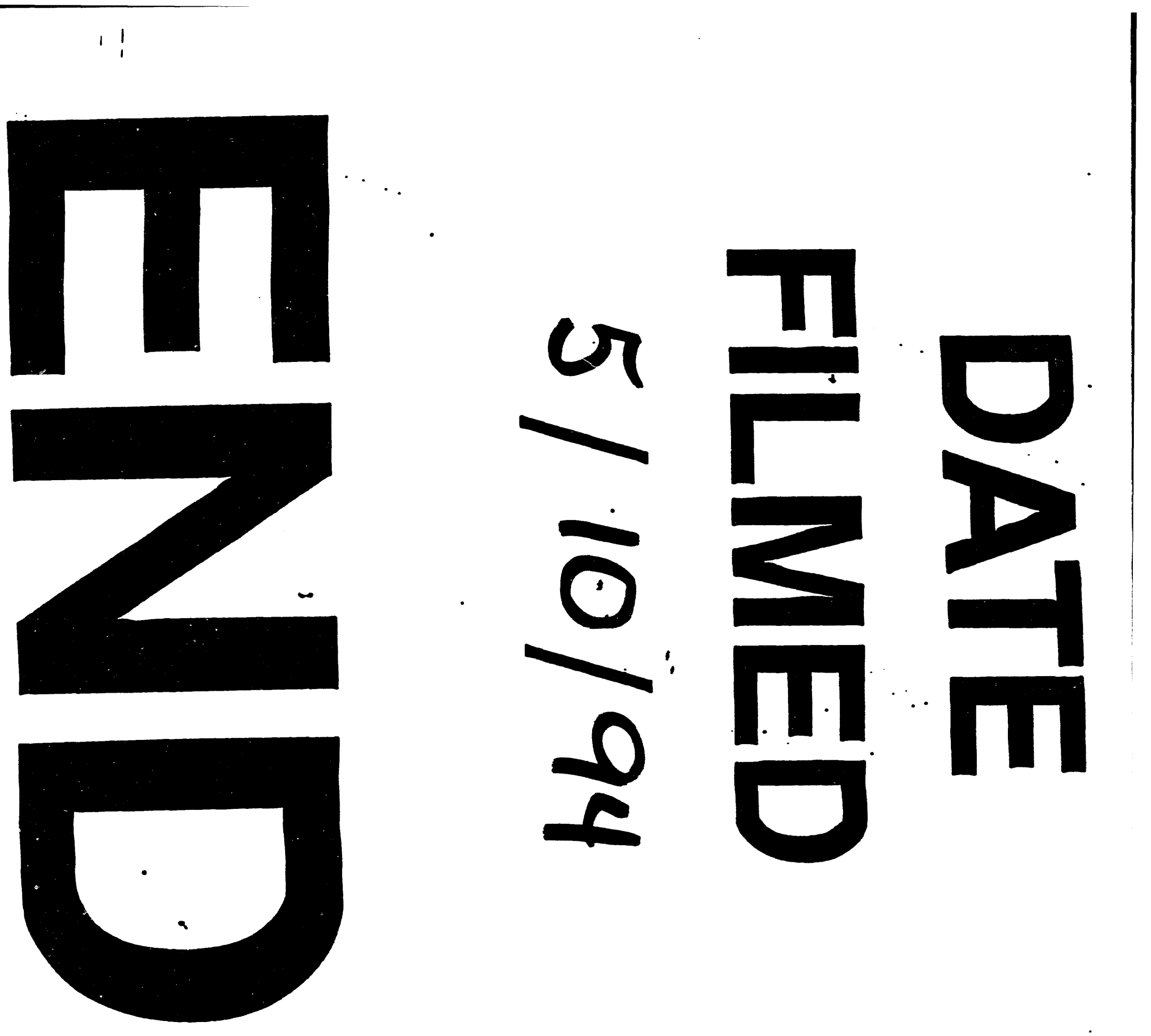
C2 